OPEN ACCESS

Edited by:

Lawrence S. Young, University of Warwick,

United Kingdom

Reviewed by:

Lisa Stockdale,

University of Oxford, United Kingdom

Rupsa Basu,

Helaina Inc., United States

*Correspondence:

Xinle Cui

xinle.cui@nih,gov;

jamescui2018@gmail.com

Specialty section:

This article was submitted to Vaccines and Molecular Therapeutics, a section of the journal

Frontiers in Immunology

Received: 01 July 2021 Accepted: 15 September 2021 Published: 08 October 2021

Citation:

Cui $X$ and Snapper CM (2021) Epstein Barr Virus: Development of Vaccines and Immune Cell Therapy

for EBV-Associated Diseases.

Front. Immunol. 12:734471. doi: 10.3389/fimmu.2021.734471

\section{Epstein Barr Virus: Development of Vaccines and Immune Cell Therapy for EBV-Associated Diseases}

\author{
Xinle Cui ${ }^{1,2 *}$ and Clifford M. Snapper ${ }^{2,3}$ \\ ${ }_{1}^{1}$ Genitourinary Malignancies Branch, Center for Cancer Research, National Cancer Institute, National Institutes of Health, \\ Bethesda, MD, United States, 2 The Institute for Vaccine Research and Department of Pathology, Uniformed Services \\ University of the Health Sciences, Bethesda, MD, United States, ${ }^{3}$ Citranvi Biosciences LLC, Chapel Hill, NC, United States
}

Epstein-Barr virus (EBV) is the first human tumor virus discovered and is strongly implicated in the etiology of multiple lymphoid and epithelial cancers. Each year EBV associated cancers account for over 200,000 new cases of cancer and cause 150,000 deaths world-wide. EBV is also the primary cause of infectious mononucleosis, and up to $70 \%$ of adolescents and young adults in developed countries suffer from infectious mononucleosis. In addition, EBV has been shown to play a critical role in the pathogenesis of multiple sclerosis. An EBV prophylactic vaccine that induces neutralizing antibodies holds great promise for prevention of EBV associated diseases. EBV envelope proteins including $\mathrm{gH} / \mathrm{gL}, \mathrm{gB}$ and gp350 play key roles in EBV entry and infection of target cells, and neutralizing antibodies elicited by each of these proteins have shown to prevent EBV infection of target cells and markedly decrease EBV titers in the peripheral blood of humanized mice challenged with lethal dose EBV. Recent studies demonstrated that immunization with the combination of $\mathrm{gH} / \mathrm{gL}, \mathrm{gB}$ and/or gp350 induced markedly increased synergistic EBV neutralizing activity compared to immunization with individual proteins. As previous clinical trials focused on gp350 alone were partially successful, the inclusion of $\mathrm{gH} / \mathrm{gL}$ and $\mathrm{gB}$ in a vaccine formulation with gp350 represents a promising approach of EBV prophylactic vaccine development. Therapeutic EBV vaccines have also been tested clinically with encouraging results. Immunization with various vaccine platforms expressing the EBV latent proteins EBNA1, LMP1, and/or LMP2 promoted specific CD4+ and CD8+ cytotoxic responses with anti-tumor activity. The addition of EBV envelope proteins $\mathrm{gH} / \mathrm{gL}, \mathrm{gB}$ and gp350 has the potential to increase the efficacy of a therapeutic EBV vaccine. The immune system plays a critical role in the control of tumors, and immune cell therapy has emerged as a promising treatment of cancers. Adoptive Tcell therapy has been successfully used in the prevention and treatment of post-transplant lymphoproliferative disorder. Chimeric antigen receptor T cell therapy and T cell receptor engineered T cell therapy targeting EBV latent proteins LMP1, LMP2 and/or EBNA1 have been in development, with the goal to increase the specificity and efficacy of treatment of EBV associated cancers.

Keywords: Epstein-Barr virus, EBV-associated cancer, EBV prophylactic vaccine, therapeutic EBV vaccine, adoptive T-cell therapy, chimeric antigen receptor $\mathrm{T}$ cell therapy, $\mathrm{T}$ cell receptor engineered $\mathrm{T}$ cell therapy 


\section{INTRODUCTION}

Epstein-Barr virus (EBV) is a gamma human herpesvirus that primarily infects B cells and epithelial cells. EBV is the primary cause of infectious mononucleosis $(1,2)$. There are $\sim 125,000$ new cases of infectious mononucleosis each year in the United States, and it is the most common cause of lost time for new Army recruits (3-5). Infectious mononucleosis could cause persistent fatigue for up to 6 months and cause severe neurologic, hematologic, or liver complications $(2,3,6,7)$. EBV is also the first human tumor virus discovered, and it has been strongly implicated in the etiology of multiple lymphoid and epithelial cancers, such as Burkitt lymphoma (BL), Hodgkin lymphoma (HL), post-transplant lymphoproliferative disorder (PTLD), nasopharyngeal carcinoma (NPC), and gastric carcinoma (GC) (8-11). Overall EBV associated cancers account for over 200,000 new cases of cancer and cause 150,000 deaths world-wide each year $(3,8,10)$. Patients undergoing solid organ or stem cell transplantation are at risk of developing uncontrolled B cell proliferation due to EBV reactivation, termed PTLD that can evolve into Hodgkin lymphoma or non-Hodgkin lymphoma, and a similar phenomenon also occurs in patients with AIDS (3, 12-14). A role for EBV has also been suggested in the pathogenesis of T and NK cell lymphomas, aggressive NK cell leukemia, and lymphoepithelioma-like carcinoma of the lung, salivary gland and thymus (15-17). Many studies further suggest a possible role for $\mathrm{EBV}$ in the pathogenesis of several autoimmune diseases, including multiple sclerosis, systemic lupus erythematosus, rheumatoid arthritis and Sjogren's syndrome $(7,18)$. In addition, there is evidence suggesting that childhood EBV infection in sub-Saharan Africa may worsen the clinical course of malaria (19). It has also been proposed that EBV infection in the oral cavity may play an important role in promoting chronic periodontitis (20).

EBV prophylactic vaccine aiming at prevention of primary EBV infection has been in development for more than 30 years, and clinical trials of therapeutic EBV vaccines targeting EBV associated cancers have been conducted for more than 10 years. Though neither an EBV prophylactic vaccine nor a therapeutic EBV vaccine has been licensed, promising progresses have been made. Encouraged by the spectacular results of CAR-T cell therapy targeting B cell antigens, CAR-T cell therapy and TCR engineered $\mathrm{T}$ cell therapy targeting $\mathrm{EBV}$ antigens are in development, with the goal of development of highly efficient treatment for EBV associated cancers and avoid the adverse effects of targeting B cell antigen.

\section{EPSTEIN-BARR VIRUS}

EBV has a linear, double-stranded DNA genome that is approximately 170 kilobase pairs in length, which encodes more than 80 proteins and 46 functional small untranslated RNAs $(21,22)$. EBV is typically transmitted via saliva and contracted during infancy in developing countries, whereas in the developed world, it is typically contracted during adolescence $(5,23)$. EBV infects $>95 \%$ of the world population by adulthood. The target cells of EBV are B lymphocytes and epithelial cells, and the mechanism by which EBV enters into host cells is shared in many aspects by other members of the herpesvirus family (2428). Infection of $B$ cells with EBV is initiated by binding of the EBV envelope protein gp350 to the complement receptor 2 (CR2)/CD21. Upon binding to B cell CR2, EBV gp42 interacts with the host cell surface MHC-II, leading to its association with the heterodimeric protein $\mathrm{gH} / \mathrm{gL}$. EBV gH/gL then activates the EBV fusion protein $\mathrm{gB}$, that directly mediates viral-host cell endosomal membrane fusion [(25-27), Figure 1A]. EBV infection of epithelial cells involves EBV BMRF2 binding to integrins, followed by $\mathrm{gH} / \mathrm{gL}$ binding to integrins and ephrin receptor $\mathrm{A} 2$, triggering activation of $\mathrm{gB}$ and fusion of the viral envelope to the plasma membrane of the epithelial cell $[(7,28-$ 36), Figure 1B]. Thus, EBV envelope glycoproteins $\mathrm{gH} / \mathrm{gL}, \mathrm{gB}$ and gp350 play key roles in EBV infection of target cells, where $\mathrm{gH} / \mathrm{gL}$ and $\mathrm{gB}$ constitute the "core fusion machinery" mediating fusion with the cell membrane $(24,25,28)$. The native conformation of EBV $\mathrm{gB}$ is a trimer, and $\mathrm{EBV} \mathrm{gH}$ and $\mathrm{gL}$ naturally form a heterodimer (24). EBV envelope proteins $\mathrm{gH} /$ $\mathrm{gL}$ and $\mathrm{gB}$ are essential for EBV infection of both $\mathrm{B}$ cells and epithelial cells, whereas gp350 is important for efficient infection of B cells $(24,25,28,33)$.

Once infecting the host, EBV establishes two alternative modes of infection: lytic and latent. During the lytic infection,

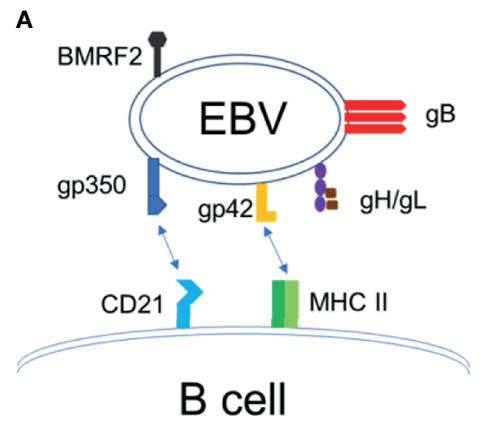

B

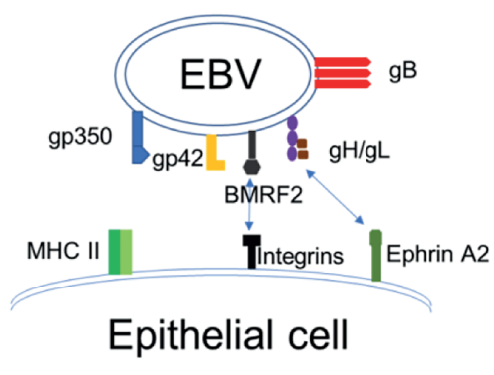

FIGURE 1 | EBV entry and infection of target cells. (A) EBV infection of B cells. (B) EBV infection of epithelial cells. 
EBV expresses more than 80 lytic proteins and these proteins facilitate the generation of new EBV viral particles and engage in immune evasion $(37,38)$. During the process of developing latency, EBV progresses through three different EBV latency programs characterized by a set of gradually restricted viral gene expression patterns, but no production of EBV virions. Through this process EBV develops eventual lifetime persistence in memory B cells $(39,40)$. Latent EBV infections play a key role in the pathogenesis of EBV associated cancer. In type III latency, all eight EBV latent antigens are expressed, including six EBV nuclear antigens (EBNA 1, EBNA2, EBNA3A, EBNA3B, EBNA $3 \mathrm{C}$ and EBNA 6/LP), and two latent membrane proteins (LMP1 and LMP2) (21). Latency III is mainly seen in PTLD and immunoblastic lymphomas in HIV infected patients (41). Latency II exists in HL, NPC and GC, where EBNA1, LMP1 and LMP2 are expressed (42). In type I latency, only EBNA1 is expressed and is seen in $\mathrm{BL}(21)$.

\section{EBV INFECTION AND INFECTIOUS MONONUCLEOSIS}

EBV is found in saliva, and is transmitted through kissing, coughing, intimate intact or sharing food and eating utensils $(43,44)$. After successful transmission, EBV infects oral epithelial cells, most likely squamous epithelial cells in the tonsil (45). EBV also infects B cells in the lymphatic tissues of Waldeyer's Ring including the tonsils (44). It is unknown whether epithelial cells or B cells are infected first. EBV replication occurs exclusively in epithelial cells which are thus responsible for EBV transmission. Epithelial cells lack MHC-II so are unable to sequester gp42 upon release of EBV virions. These virions expressing gp42, then demonstrate a preference for infection of B cells, which express MHC-II. Likewise, the presence of gp42 blocks gH binding to integrins on epithelial cells thus inhibiting epithelial cell infection. When released from B cells, MHC-II sequesters gp42 thus producing EBV virions lacking gp42 and demonstrating a preference for infecting epithelial cells (25). In developing countries primary EBV infection usually occurs during infancy and childhood with most individuals infected by 4 years of age. In contrast, in developed countries, primary EBV infection typically occurs during adolescence or early adulthood. These differences are most likely caused by socioeconomic factors (44).

Primary EBV infection in young children usually produces no significant symptoms, whereas primary EBV infection in adolescents and young adults could cause infectious mononucleosis (IM), and up to $70 \%$ of adolescents and young adults present with the classical symptoms of IM after EBV infection $(44,46)$. IM is characterized by two to four weeks of fever, pharyngitis, cervical lymphadenopathy and fatigue accompanied by a massive expansion of the number of EBVspecific CD8+ T cells after an incubation period of about six weeks $(44,47)$. Disease severity and duration of IM correlate with CD8+ $\mathrm{T}$ cell counts rather than with the viral kinetics (48-50). This indicates that IM is caused by an overreaction of the immune system due to a failure in early control of viral replications, leading to an exaggerated $\mathrm{CD} 8+\mathrm{T}$ cell response with consequent inflammatory cytokine release $(39,48,51)$. It has been suggested that infants and children, but not older individuals produce an NK cell subset important for early EBV control, thus preventing the occurrence of IM in this population (52). The vast majority of IM cases are self-limiting with an excellent prognosis, with rare cases of severe acute complications such as splenic rupture, hepatitis and airway obstruction due to tonsil enlargement $(43,44,53)$. Late complications to IM include Hodgkin lymphoma and multiple sclerosis (21). Life-long latent EBV infection establishes following primary infection (41).

\section{EBV ASSOCIATED CANCERS}

EBV is the first human tumor virus identified. EBV not only causes infectious mononucleosis, it is also strongly associated with epithelial cell cancers such as nasopharyngeal cancer (NPC), gastric cancer as well as lymphoid cancers such as Burkitt lymphoma (BL), Hodgkin lymphoma (HL) and post transplantation lymphoproliferative disorder (PTLD) (8-14). NPC is endemic in southeast Asia, and the vast majority are the nonkeratinized type, accounting for 80,000 new cases each year worldwide $(10,41,54)$. Nonkeratinized NPC displays a lymphoepithelial-like (LEL) appearance with a marked lymphocytic infiltration, which is $100 \%$ EBV positive (41). About $10 \%$ of gastric cancers are associated with EBV infection, have a similar LEL pathological change and are EBV positive, accounting for about 83,000 new cases each year $(41,55$, 56). Essentially all Burkitt lymphoma in equatorial Africa and in Papua New Guinea, are EBV genome-positive, accounting for 7,000 new cases each year (57-59). Hodgkin lymphoma is also strongly associated with EBV, especially the mixed cellularity subtype, of which $80-90 \%$ are EBV positive (60-63). PTLD is another example that EBV plays a critical role in cancer pathogenesis, all the cases of PTLD are EBV positive, and adoptive transfer of EBV specific T cells could prevent or cure the disease (64-68). The role of EBV in cancer pathogenesis has also been confirmed in animal models, as inoculation of cotton top tamarins or humanized mice with high titers of EBV results in the development of B-cell lymphomas and lymphoproliferative disease that are seen in humans (69-78).

\section{Burkitt's Lymphoma}

Burkitt's lymphoma (BL) is highly aggressive and it is the most common pediatric cancer in the world $(42,58)$. Based on clinical observations and disease epidemiology, BL is classified into three different forms: endemic, sporadic and immunodeficiencyassociated BLs (79). Endemic BL occurs in equatorial Africa and in Papua New Guinea, where essentially all cases are EBV genome-positive $(41,80)$. Sporadic BL has a wide global distribution, but has a much lower frequency with only 10 $15 \%$ linked to EBV except for North East Brazil where the frequency of EBV in sporadic BL exceeds $80 \%(81,82)$. Immunodeficiency-associated $\mathrm{BL}$ has been diagnosed in HIV carriers who develop the lymphoma before progressing to AIDS, 
with an incidence of 10 to 100 -fold higher than that of the sporadic BL, and about 30-40\% of Immunodeficiency-associated $\mathrm{BL}$ are positive for $\operatorname{EBV}(41,83,84)$.

BLs have a characteristic histology with sheets of monomorphic tumor cells resembling germinal centroblasts interspersed with macrophages, and have hypermutated Ig gene sequences typical of their geminal center (GC) origin and all carry chromosomal translocations that bring the c-myc gene under the control of either the Ig heavy chain or light chain loci (84). The resultant deregulation leading to constitutive expression of c-myc proteins at high levels in $\mathrm{BL}$ cells, and causes uncontrolled cell growth in BL (85). The expression of $\mathrm{EBV}$ genes in EBV positive $\mathrm{BL}$ is restricted to the type I latency program, where only EBNA-1 is expressed (86). Though the mechanism of EBV in the pathogenesis of BL is still unclear, it has been shown the expression of EBNA-1 in BL cell lines promotes cell proliferation by inhibiting apoptosis (87). Also, coinfection with other pathogens seem to play an important role, such as coinfection of EBV and Plasmodium falciparum in endemic BL, and coinfection of EBV and HIV in immunodeficiency-associated BLs $(88,89)$.

\section{Hodgkin Lymphoma}

Hodgkin lymphoma (HL) originates from B cell and is characterized by the presence of few malignant multinucleated giant Reed Sternberg cells surrounded by a massively outnumbered non-neoplastic inflammatory infiltrate (41). Based on the nature of the infiltrate, classical HL is divided into four histologic subtypes namely the mixed cellularity (MC), nodular sclerosing (NS) and the rarer lymphocyte rich (LR) and lymphocyte-depleted (LD) subtypes (60). A minor, non-classical subtype of HL is referred to as lymphocyte predominant (LP). About $96 \%$ of MC cases are EBV genome-positive, whereas only $15-20 \%$ of cases of NS are associated with EBV. The rarer LR subtype is associated with EBV in $40 \%$ of cases, and most LD cases are $\mathrm{EBV}+(42,90)$. EBV is not associated with the nonclassical LP subtype (91). Overall, about $30-40 \%$ of HL cases in North America and Europe were reported to be EBV positive, but in Latin America, Africa and Asia, EBV was found in almost $100 \%$ of all HL cases (91).

The Reed Sternberg cells in HL are B cells arrested at the germinal center (GC) or post-GC stages of B cell differentiation where somatic mutations in immunoglobulin (Ig) $\mathrm{V}$ genes are detected (92-95). The Reed Sternberg cells of the classical type of HL fail to express most B cell-specific genes, including Ig genes (91). Though the role of EBV in HL pathogenesis is still not fully understood, it is reported that all EBV-positive tumors consistently exhibit Latency II infection with high levels of the LMP1 and LMP2A proteins maintained in every Reed-Sternberg cell (41). LMP1 functions as a constitutively active variant of the CD40 receptor, and activates the aberrant transcriptional programs in Reed Sternberg cells, including the NF- $\mathrm{KB}$, JAK/ STAT, AP-1, and (PI3K)/AKT pathways (96-103). LMP1 could also promote the survival of EBV-infected B cell receptor (BCR)negative Reed Sternberg progenitors and increase the expression of anti-apoptotic molecules, including BCL2 and MCL1 (104106). LMP2A mimics BCR, allows B cell development in the absence of BCR signaling, activates RAS/PI3K/AKT signaling and the mTOR pathway (107-111). LMP2A is also critical for the EBV-induced immortalization of BCR-negative GC B cells and LMP2A expression in different B cells systems can induce many of the cellular transcriptional changes characteristic of Reed Sternberg cells (112-117).

\section{Post-Transplant Lymphoproliferative Disorder}

Post-transplant lymphoproliferative disorder (PTLD) is an uncontrolled B cell proliferation observed in some patients after solid organ or hematopoietic stem cell transplantation that can lead to non-Hodgkin and Hodgkin lymphoma (118). The prevalence of EBV-associated PTLD ranges from 1-20\%, with incidence varying according to the type of allograft, age, and pretransplant EBV serostatus of transplant recipient (42). PTLD occurs as a result of increased proliferation of B cells due to either primary EBV infection, or reactivation of EBV from latently infected cells after treatment with immunosuppressant to avoid allograft rejection (119). The genome of EBV has been found in all of the B cells from PTLD patients. The use of immune suppressive drugs after organ transplant leads to depletion of EBV-specific T cells, and the impairment of EBV-specific T cell mediated immune surveillance results in uncontrolled lymphoproliferative blast, which causes PTLD in transplant recipients (119-122). PTLD display Latency III infection, and all the eight EBV latent antigens are expressed, including six EBV nuclear antigens EBNA 1, EBNA2, EBNA3A, EBNA3B, EBNA 3C, EBNA 6/LP and two latent membrane proteins LMP1 and LMP2 $(41,42)$. These latent EBV proteins play key roles in the uncontrolled proliferation of $\mathrm{B}$ cells, and they are also the targets of EBV specific CD8+ T cells $(21,123)$.

\section{Nasopharyngeal Cancer}

Nasopharyngeal cancer (NPC) is a squamous cell epithelial tumor that arises from the lateral wall of nasopharynx, including the fossa of Rosenmüller and superior posterior wall (124). NPC shows remarkable variation in ethnic and geographical distribution, with about $80 \%$ cases reported in Southern China and Southeast Asia $(42,125)$. NPC rates are low in the United States and Europe, the tumor occurs at intermediate to high incidence throughout South-East Asia and reaches its peak in populations of Southern Chinese decent where NPC is endemic, with a rate that is 30 -fold higher than that of the United States and Europe (126). NPC is classified into two histological variants, namely squamous cell carcinomas (SCCs) and undifferentiated carcinomas of the nasopharyngeal type (UCNT) $(42,127)$. In a non-endemic region, about $63 \%$ of NPC cases are UCNT, while in Southern China, more than $95 \%$ of the cases are UCNT (128). Irrespective of geography and of incidence rate, all cases of undifferentiated NPC worldwide are EBV-associated, and the EBV genome present in every malignant cell (10).

Though genetic element and lifestyle/environmental factor contribute to NPC risk, EBV infection plays a critical role in NPC pathogenesis $(41,42)$. The viral infection in NPC epithelial cells 
is clonal, developed from clonal proliferation of single EBV infected epithelial cell $(42,129)$. EBV viral gene expression in NPC tumor cells is an intermediate form, Latency I/II, all tumors express EBNA1, the non-coding EBERs and BART-miRs, and LMP2, whereas LMP-1 has been found in about two-thirds of NPC cases $(86,130)$. The BART-miRs and LMP2 promote epithelial cell growth (131-134). LMP1 activates the NFkB signaling pathway, which is a consistent feature of all NPCs (135).

\section{Gastric Cancer}

Gastric cancer (GC) has a worldwide annual incidence of over 950,000 cases, and ranks as the third leading cause of cancerrelated mortality globally (42). Though $75 \%$ of gastric cancers appear to be linked to $\mathrm{H}$. pylori infection, up to $10 \%$ of gastric cancers are EBV-positive, accounting for 90,000 new cases each year $(55,56)$. The EBV associated gastric cancers appear to form a clinically and pathogenetically distinct subgroup, occurs predominantly in the proximal stomach including the cardia, fundus and body, tend to present earlier in life, have a lower rate of lymph node involvement and a relatively favorable prognosis (56, 136-138). EBV associated gastric cancer is classified into three histological subtypes, lymphoepithelioma like carcinoma (LELC)-type, conventional adenocarcinoma (CA)-type, and carcinoma Crohn's, and more than $90 \%$ of EBV associated gastric cancers show LELC-type morphology (138). Latency I or intermediate Latency I/II EBV infection are detected in EBV associated gastric cancer cells, and all the malignant cells within an individual tumor carry the same monoclonal virus genome (139). Though the role of EBV in the pathogenesis of gastric carcinoma is poorly understood, EBV-positive gastric cancer shows a distinctive hyper-methylated genome $(140,141)$. It is proposed that EBV actively drives oncogenic change through epigenetic modification of the host cell genome, and silences tumor suppressor genes such as p16 and E cadherin (142).

\section{EBV AND MULTIPLE SCLEROSIS}

Multiple sclerosis (MS) is the most common autoimmune demyelinating disease, affecting both the brain and spinal cord. It is a lifetime, potentially debilitating condition with both remitting/relapsing and progressive phases. It typically occurs in young adults, especially Caucasians with a prevalence of $1 /$ 1,000 in this latter population and affects $\sim 2.5$ million people worldwide (143). EBV is recognized as the strongest infectious risk factor for this disease. Essentially all MS patients are EBV seropositive, and although still controversial, EBV may be a necessary pre-requisite for MS development (144). Several lines of evidence suggest an etiological role of EBV in MS, including but not limited to a high titer of anti-EBNA1 antibodies observed several years before MS onset, preliminary success of EBVspecific $\mathrm{T}$ cell therapy for treating progressive MS, and intriguing data from animal modeling (145-148). Of note, individuals carrying the HLA-DR15 gene (found in $25 \%$ of the overall population) who develop IM have at least a 10 -fold increased risk of developing MS (149). MS typically develops $>5$ years after IM. Although a prophylactic EBV vaccine holds promise for markedly reducing the incidence of MS, confirmation will likely require long-term follow-up of individuals receiving the vaccine for other indications, most likely prevention of IM.

\section{PROPHYLACTIC EBV VACCINE}

An EBV prophylactic vaccine holds great promise for prevention of cancers caused by EBV infection, as has been the case for prophylactic vaccines against human papilloma virus (HPV) and hepatitis B virus that cause $\sim 600,000$ and $\sim 400,000$ cases of new cancers each year respectively $(10,150)$. An EBV prophylactic vaccine would also be the most cost-effective approach for the management of infectious mononucleosis as well as EBV associated autoimmune disease such as MS (Table 1). A prophylactic EBV vaccine uses the strategies to induce antibody response mainly neutralizing antibodies to block EBV infection of its target cells, whereas non-neutralizing antibodies as well as cell mediated immune response further improve prophylactic efficacy. The target cells of EBV are mainly B cells and epithelial cells, and EBV requires multiple envelope proteins for cell entry. EBV infection of B cells requires envelope proteins gp350, gH, gL, gB and gp42, whereas EBV infection of epithelial cells requires envelope proteins BMFR2, gH, gL and gB, therefore these envelope proteins could be excellent EBV prophylactic vaccine candidates $[(7,25-27,33)$, Table 1$]$.

\section{Recombinant EBV Envelope Protein Vaccines}

Early efforts in EBV vaccine development were focused on gp350 (Table 1). EBV gp350 is the most abundant EBV envelope protein, and about half of the EBV neutralizing activity in EBV seropositive human sera is against gp350 $(7,161)$. Purified or recombinant gp350 was shown to protect cotton top tamarins from lymphoma caused by EBV infection, and similar results were reported with adenovirus or vaccinia virus expressing gp350 (69-76). Phase I and II studies of a recombinant gp350 produced in Chinese hamster ovary cells showed that the recombinant gp350 induced neutralizing antibodies in humans in $70 \%$ of the subjects, and reduced the rate of infectious mononucleosis by $78 \%$ in the vaccinated subjects but did not prevent EBV infection $(156,167)$. This is most likely because gp350 is not strictly essential for EBV virus infection of B cells but only important for efficient infection, as well as the inability of gp350 induced antibodies to protect against EBV infection of epithelial cells $(24,25,28,33,168)$.

Our group was the first to report in 2016 that recombinant EBV $\mathrm{gH} / \mathrm{gL}$ and $\mathrm{gB}$ proteins induced markedly higher EBV neutralizing antibodies compared to gp350, where a trimeric form of $\mathrm{gH} / \mathrm{gL}$ and a tetrameric form of gp350 elicited significantly higher EBV neutralizing activities compared to their monomeric counterparts (159). This was confirmed by the recently published study by $\mathrm{Bu}$ et al. that $\mathrm{EBV} \mathrm{gH} / \mathrm{gL}$ or $\mathrm{gH} /$ 
TABLE 1 | Summary of prophylactic EBV vaccines.

Platform/Antigen/Adjuvant

$\begin{array}{ccc}\begin{array}{c}\text { Animal/ } \\ \text { Clinical } \\ \text { trial }\end{array} & \begin{array}{c}\text { Published } \\ \text { year }\end{array} & \text { Results } \\ & & \end{array}$

\section{EBV envelope protein vaccines}

Subunit vaccine, purified full length gp340 from virus, with liposome, Freund's adjuvant, lipid A

\begin{tabular}{|c|c|c|}
\hline $\begin{array}{l}\text { Mice, } \\
\text { Cottontop } \\
\text { tamarins }\end{array}$ & 1984 & Antibody responses were induced (70). \\
\hline $\begin{array}{l}\text { Cottontop } \\
\text { tamarins }\end{array}$ & 1985 & Protection against malignant lymphoma (151). \\
\hline Rabbits & 1988 & EBV-specific neutralizing antibodies were induced (152). \\
\hline $\begin{array}{l}\text { Cottontop } \\
\text { tamarins }\end{array}$ & 1988 & Protection against malignant lymphoma (153). \\
\hline $\begin{array}{l}\text { Cottontop } \\
\text { tamarins }\end{array}$ & 1994 & $\begin{array}{l}\text { Protection of } 3 / 5 \text { cottontop tamarins against malignant } \\
\text { lymphoma (154). }\end{array}$ \\
\hline Rabbits & 1999 & High titers of neutralizing antibody elicited (155). \\
\hline Phase II & 2007 & $\begin{array}{l}\text { Induced neutralizing antibodies in } 70 \% \text { of human subjects, } \\
\text { and decreased IM by } 78 \% \text { (156). }\end{array}$ \\
\hline Mice & 2013 & $\begin{array}{l}\text { Tetrameric gp350 induced } \sim 20 \text { - fold higher titers of IgG and } \\
>19 \text {-fold higher neutralizing titers at the highest dose (157). }\end{array}$ \\
\hline Mice & 2015 & $\begin{array}{l}\text { gp350-nanoparticle elicited 10- to 100-fold higher neutralizing } \\
\text { titers compared to soluble gp350 (158). }\end{array}$ \\
\hline Rabbits & 2016 & $\begin{array}{l}\text { Trimeric and monomeric } \mathrm{gH} / \mathrm{gL} \text {, trimeric gB, and tetrameric } \\
\text { gp350 induced EBV-neutralizing titers }>100-, 20-, \text { 18-, and 4- } \\
\text { fold higher, respectively, than monomeric gp350 (159). }\end{array}$ \\
\hline Mice & 2018 & $\begin{array}{l}\text { Elicited significantly higher neutralizing titers than gp350 } \\
\text { monomer (160). }\end{array}$ \\
\hline $\begin{array}{l}\text { Mice, } \\
\text { cynomolgus } \\
\text { macaques }\end{array}$ & 2019 & $\begin{array}{l}\mathrm{gH} / \mathrm{gL} \text { and } \mathrm{gH} / \mathrm{gL} / \mathrm{gp} 42 \text {-ferritin nanoparticles elicited }>40-\text { and } \\
\sim 4 \text {-fold higher neutralization titers for } \mathrm{B} \text { cells in monkeys } \\
\text { compared with soluble proteins; for epithelial cells, }>25 \text { - and } \\
\sim 4 \text {-fold higher neutralizing titers were elicited. (161). }\end{array}$ \\
\hline $\begin{array}{l}\text { Rabbits, } \\
\text { humanized } \\
\text { mice }\end{array}$ & 2021 & $\begin{array}{l}\text { Sera from rabbits immunized trimeric } \mathrm{gB} \text { or monomeric } \mathrm{gH} / \mathrm{gL} \\
\text { protected humanized mice from lethal dose EBV challenge } \\
\text { and markedly decreased EBV loads. Immunization with the } \\
\text { combination of } \mathrm{gB} \text { and } \mathrm{gH} / \mathrm{gL} \text { elicited strong synergistic } \\
\text { neutralizing activity (162). }\end{array}$ \\
\hline
\end{tabular}

\section{Subunit vaccine, Purified full length gp340 from virus}

Subunit vaccine, purified gp350/gp220 from yeast and mammalian cells Subunit vaccine, purified gp340, incorporated into immune-stimulating complexes

Subunit vaccine, recombinant gp340 adjuvanted with Alum

Subunit vaccine, recombinant single chain gp350 with Freund's adjuvant versus Alum

Subunit vaccine, recombinant single chain gp350 with ASO4 versus alum

Subunit vaccine, recombinant tetrameric versus monomeric gp $350^{1-470}$ adjuvanted with alum/CpG-ODN

Subunit vaccine, self- assembling nanoparticles expressing gp $350^{1-123}$

Subunit vaccine, recombinant monomeric $\mathrm{gH} / \mathrm{gL}$, trimeric $\mathrm{gH} / \mathrm{gL}$ and trimeric gB, adjuvanted with alum/CpG-ODN

Subunit vaccine, Fc-fused gp350 dimer with Alum

Subunit vaccine, self-assembling nanoparticles expressing $\mathrm{gH} / \mathrm{gL}$ or $\mathrm{gH} / \mathrm{gL}$ gp42 with SAS adjuvant

Subunit vaccine, recombinant trimeric $\mathrm{gB}$, monomeric $\mathrm{gH} / \mathrm{gL}$ and their combination, adjuvanted with alum/CpG-ODN

\section{Mice \\ Humanized \\ mice \\ Mice \\ Mice}

EBV-derived VLP, produced via the deletion of the EBV terminal repeats, EBNA2, EBNA 3A, 3B and 3C, LMP1 and BZLF1

EBV-derived VLP, produced by fusing EBNA1 and EBNA3C to the major tegument protein BNRF1

Newcastle disease virus (NDV) VLP, expressing gp350/220 Ectodomain

NDV VLP, expressing gH/gL-EBNA1 or gB-LMP2

\section{Synthesized mRNA EBV vaccines}

Synthesized mRNA encoding gp350, gB, gH/gL and gp42
Mice
2011 EBV-specific humoral and cellular immune responses were induced (163).

2018 Potent CD4+ T cell responses elicited, and EBV loads were reduced (164).

2015 Elicited neutralizing antibody responses, but not higher than that of soluble gp350/220 (165).

2017 Elicited EBV-specific T-cell responses and higher EBV neutralizing titers (166).

2021 Elicited $\sim 20$ - and 100-fold higher neutralizing activities for B cells and epithelial cells respectively compared to human sera.
gL/gp42 nanoparticles induced potent neutralizing antibody responses in mice and non-human primates, which blocked EBV-target cell fusion and prevented EBV infection of B cells and epithelial cells (161). Though these nanoparticle EBV vaccine candidates induced 10 - to 1000 -fold higher titers of neutralizing antibodies compared to that of soluble proteins, as the $\mathrm{gH}, \mathrm{gL}$ and/or gp42 proteins were highly packed into the nanoparticles, the expression of native conformational epitopes of these EBV envelope proteins could be prevented (161). It was reported that virus like particles and nanoparticles could induce quantitatively high antibody responses whereas recombinant proteins expressing native epitopes could elicit antibody responses that are high both quantitatively and qualitatively (169-172). This has been confirmed with the herpes virus recombinant envelope protein vaccine candidates produced in our laboratory including EBV gH/gL and EBV trimeric gB (159, $173,174)$.

EBV $\mathrm{gH} / \mathrm{gL}$ and $\mathrm{gB}$ constitute the core fusion machinery, which play the critical roles for EBV fusion and entry into all target cells, thus making the inclusion of EBV $\mathrm{gH} / \mathrm{gL}$ and $\mathrm{gB}$ more promising as prophylactic EBV vaccine candidates than the use of gp350 alone $(24,25,28)$. As EBV gH/gL and gB could both elicit neutralizing antibodies, the presence of $\mathrm{gH} / \mathrm{gL}$ neutralizing antibodies and gB neutralizing antibodies simultaneously would most likely exhibit synergistic effects $(7,24,33)$. In this regard, we recently demonstrated that mixing $\mathrm{EBV} \mathrm{gH} / \mathrm{gL}$ anti-sera with EBV gB anti-sera resulted in strong synergistic neutralizing activity for both B cells and epithelial cells. This may have 
been due to the ability of $\mathrm{gH} / \mathrm{gL}$ and $\mathrm{gB}$ antibodies to block different steps in EBV infection of target cells (162). Immunization with the combination of $\mathrm{EBV} \mathrm{gH} / \mathrm{gL}$ and trimeric gB also elicited markedly higher EBV neutralizing activities for both B cells and epithelial cells as compared to that induced by immunization with $\mathrm{EBV} \mathrm{gH} / \mathrm{gL}$ or trimeric $\mathrm{gB}$ alone, demonstrating strong synergistic effects of EBV core fusion envelope proteins in elicitation of neutralizing antibodies (162). The strong synergistic effects are most likely due to the sequential coordination of these envelope proteins in mediating EBV entry and infection of target cells, suggesting that the combination of EBV core fusion machinery envelope proteins $\mathrm{gH} / \mathrm{gL}$ and trimeric $\mathrm{gB}$ could be a highly effective EBV prophylactic vaccine. Recombinant gp350 also demonstrated synergistic EBV neutralizing activities when used with EBV gH/gL and/or gB (175). Further, we recently reported that the immune sera from rabbits immunized with $\mathrm{EBV} \mathrm{gH} / \mathrm{gL}$ or trimeric gB protected humanized mice from death after lethal dose EBV challenge and markedly decreased the EBV in peripheral blood (162). Collectively, these data strongly suggest that the combination of EBV gH/gL, gB and gp350 could be an ideal EBV prophylactic vaccine that can elicit markedly high synergistic EBV neutralizing activity with the potential to induce sterilizing immunity. EBV gp350, gH, gL, and gB can also induce $\mathrm{CD} 4+$ and $\mathrm{CD} 8+\mathrm{T}$ cell immune responses, and have demonstrated to inhibit proliferation of EBV-infected primary B cells in vitro before latency was established $(40,176,177)$. The $\mathrm{T}$ cell immune responses induced by EBV gp350, gH, gL, and gB could further increase the efficacy of a prophylactic vaccine by promoting the killing of recently infected epithelial cells and $\mathrm{B}$ cells and stopping B-cell transformation if the EBV is not blocked by neutralizing antibodies.

\section{Virus-Like Particle EBV Vaccines}

Virus-Like particle (VLP) vaccines have been successfully developed for hepatitis $B$ virus and human papilloma virus, but the development of VLP vaccines for EBV has met challenges. The first successful EBV VLPs were created by the deletion of the EBV terminal repeats, and potential oncogenes namely EBNA2, 3A, 3B and 3C, LMP1 and BZLF1 (163). These EBV VLPs were shown to elicit EBV-specific humoral and cellular immune responses after immunization in mice (163). Later, the viral packaging and nuclear egress proteins BFLF1/ BFRF1A were further deleted to improve safety, and the EBV VLPs produced could induce comparable CD4+ T cell responses as that of wildtype EBV, but the responses against structural proteins were reduced. More immunogenic EBV VLPs were made by fusing latent antigens EBNA1 and EBNA3C to the major tegument protein BNRF1 of EBV. The EBV VLPs produced were able to stimulate potent $\mathrm{CD} 4+\mathrm{T}$ cell responses against structural as well as latent EBV protein epitopes, and reduced EBV loads in the peripheral blood of humanized mice after immunization (164). However, the possibility of repacking of EBV DNA remains a safety concern for the EBV-derived VLPs. Another approach used a novel Newcastle disease virus (NDV) VLP platform displaying the EBV gp350/220 ectodomain, but the EBV neutralizing titers elicited in mice were not significantly higher than that induced by soluble gp350/ 220 (165). The NDV VLP platform was subsequently used to produce gH/gL-EBNA1 VLPs and gB/LMP2 VLPs. Both elicited higher EBV neutralizing titers in mice, but not comparable to that elicited by UV-inactivated EBV, suggesting potency concerns with the NDV VLP EBV vaccines (166).

\section{Synthesized mRNA EBV Vaccines}

The rapid and successful development of synthesized mRNA vaccines against SARS-CoV2 for the COVID-19 pandemic has encouraged the development of synthesized mRNA EBV vaccines $(178,179)$. After demonstrating its mRNA vaccine candidate encoding gp350, gB, gH/gL and gp42 induced significantly higher EBV neutralizing titers in mice compared to human sera, Moderna has initiated phase I clinical trial of its mRNA EBV vaccine. However, there are potential challenges with this approach. First, whether mRNA vaccines could induce long-term memory responses in humans remains to be determined, and may require repeated booster immunizations to maintain high titers of neutralizing antibodies and potent $\mathrm{T}$ cell immune responses. This would be unacceptable for pathogens such as EBV that rarely cause a medical emergency. Second, mRNA is an intrinsic adjuvant that may limit multicomponent formulations because of unacceptable side effects. Currently it has been reported that mRNA vaccines against SARS-CoV2 may have caused myocarditis and pericarditis in a small number of subjects. Long-term adverse effects as well as adverse effects after multiple repeated immunizations are still unknown.

\section{Viral Vector EBV Vaccines}

The viral vector vaccine platform has mainly been used for the development of therapeutic EBV vaccines, which are discussed in detail later in the therapeutic EBV vaccine section.

\section{THERAPEUTIC EBV VACCINE}

The immune system plays a critical role in the control of tumors, and the immune-based tumor-specific therapeutic approaches could be highly effective with limited adverse effects (21). Therapeutic EBV vaccines aim at boosting the existing or inducing novel antiviral adaptive immune responses in patients with EBV-associated cancers (21). The targets of EBV therapeutic vaccines are focused on EBNA1, LMP2 and/or LMP1, as these proteins are involved in the modulation of key factors that contribute to the transformation of normal cells into tumors [(180-185), Table 2]. Most therapeutic EBV vaccination approaches have focused on patients with NPC, and early clinical trials were done with dendritic cells (DCs)-based EBV vaccines (21). Autologous monocyte-derived dendritic cells (DCs) from NPC patients pulsed with HLA-A11-, -A24-, or -B4-restricted LMP2 epitopes boosted EBV-specific CD8+ T-cell responses in nine of 16 patients, and induced partial tumor regression in two patients (191). In another phase I clinical trial where 16 HLA-A2+ NPC patients were vaccinated with autologous DCs pulsed with 
TABLE 2 | Summary of therapeutic EBV vaccines.

\begin{tabular}{|c|c|c|c|c|}
\hline Platform/Antigen & Disease & $\begin{array}{l}\text { Clinical } \\
\text { trial }\end{array}$ & $\begin{array}{l}\text { Published } \\
\text { year }\end{array}$ & Results \\
\hline \multicolumn{5}{|l|}{ 1. Dendritic cells (DCs)-based EBV vaccines } \\
\hline Autologous DCs pulsed with LMP2A peptides & NPC & Phase I & 2013 & $\begin{array}{l}\text { LMP2-specific T-cell response improved in 9/16 patients, with } \\
\text { decreased serum EBV load (187). }\end{array}$ \\
\hline \multicolumn{5}{|l|}{ 2. Recombinant viral vector vaccines } \\
\hline MVA-EL & NPC & Phase I & & $\begin{array}{l}\text { Increased numbers and differentiationof CD4+ and CD8+ T-cells } \\
\text { to EBNA1 and LMP2 in } 4 / 8 \text { patients (190). }\end{array}$ \\
\hline
\end{tabular}

HLA-A2-restricted LMP2A peptides, the LMP2-specific T-cell response was improved in 9 of 16 patients, which correlated with a modest decrease in serum EBV DNA levels (187).

Recombinant viral vector vaccines were later developed to present a wide range of epitopes to improve efficacy. One of the approaches used a recombinant adenoviral vector to deliver LMP2 antigen, and demonstrated a dose dependent increase in the proportion of LMP2-specific CD3+ CD4+ cells in the peripheral blood of immunized NPC patients in a clinical trial (188). A modified vaccinia ankara (MVA) expressing the carboxyl terminus of EBNA1 and full-length LMP2 as a fusion protein (MVA-EL) was shown to efficiently expand the EBNA1and LMP2-specific CD4+ and CD8+ T cells from the peripheral blood lymphocytes of seropositive healthy donors in vitro (192). A phase I clinical trial of the MVA-EL vaccine carried out in Hong Kong where NPC patients in remission received three intradermal MVA-EL immunizations at 3-weekly intervals, and demonstrated a two-fold increase in the T-cell response to one or both vaccine antigens in 15 of 18 treated patients (189). Further, these $\mathrm{T}$-cell responses were mapped to known CD4+ and CD8+ T-cell epitopes of EBNA1 and/or LMP2 (189). A second phase I clinical trial of the MVA-EL vaccine conducted in UK showed an increase in CD4+ and CD8+ T-cell responses to one or both of the antigens in 8 of the 14 NPC patients tested, as well as increased differentiation and functional diversification in the EBNA1- and LMP2-specific CD4+ and CD8+ cells (190).

Though the EBV therapeutic vaccine clinical trials have shown many potential clinical benefits, further remains to be done. The DC vaccines can only deliver limited antigen epitopes and are expensive to prepare (21). Recombinant viral vector vaccines can deliver a wide range of epitopes, but the anti-viral vector immune responses elicited after repeated immunizations are a big obstacle, which could markedly decrease the efficacy of viral vector vaccines. Different vaccine platforms should be explored for the development of EBV therapeutic vaccines. Although T-cell responses were believed to be critical in controlling EBV-associated cancers, high levels of neutralizing antibodies are associated with a lower risk of NPC, and NPC progression has been shown to correlate with active EBV replication and high titers of EBV in the peripheral blood, thus a vaccine inducing potent EBV neutralizing antibodies may reduce the risk of EBV-related cancers $(21,193)$. The role of the neutralizing antibody response in EBV-associated malignancies needs to be explored further. A vaccine platform delivering EBNA1, LMP1/LMP2, gp350, gH/gL and gB simultaneously may significantly increase the efficacy of a therapeutic vaccine against EBV associated cancers.

\section{IMMUNOTHERAPY AGAINST EBV ASSOCIATED CANCER}

\section{Adoptive T-Cell Therapy}

Adoptive T-cell therapy (ACT) has been successfully used for the treatment of PTLD, and the reconstitution of cellular immunity provides a powerful mechanism to control EBV-associated PTLD [(21), Table 3]. The first ACT clinical trial demonstrated that infusion of donor-derived EBV-specific T lymphocytes into allogeneic hematopoietic stem cell transplantation (HSCT) patients with donor-derived EBV-associated immunoblastic lymphoma induced a complete regression in 5/5 patients, but graft-versus-host disease (GvHD) was developed due to the alloreactive T cells (194). Later EBV-specific cytotoxic T lymphocytes (CTLs) were obtained by in vitro stimulation with EBV-transformed B lymphoblastoid cell lines (LCLs), synthetic peptides or recombinant viral vectors, and followed by selection with TCR tetramer binding or IFN- $\gamma$ capture. Clinical trials demonstrated that these in vitro-expanded donor-derived EBVspecific CTLs could be used effectively for the prevention and treatment of PTLD in HSCT patients with minimal alloreactivity (64-66). Similar strategies were also used to expand in vitro the autologous EBV-specific CTLs from highly immunosuppressed solid organ transplantation (SOT) patients and successfully controlled EBV-associated PTLD (195-197). Encouraged by the excellent results of treatment of PTLD with ACT, ACTs have been developed for NPC and HL using in vitro expanded CTLs targeting type II latency antigens EBNA1, LMP1 and LMP2 [(198, 199, 206208), Table 3]. Clinical trials with these expanded CTLs significantly increased response rates as well as overall survival in both NPC and HL patients $(186,200,201)$.

\section{EBV Specific T Cell Receptor Engineered T Cell Therapy}

$\mathrm{T}$ cell receptor (TCR) engineered $\mathrm{T}$ cell therapy is a promising approach to cancer treatment, and has been used in the 
treatment of HPV associated cancer targeting E7 antigen with impressive results (209-211). TCRs that recognize EBNA3A, EBNA3B, LMP1, LMP2, BRLF1 and BMLF1 have been generated from specific CD8+ T cell clones, and tested their effectiveness in eliminating EBV transformed B cells (212-214). It was reported that the $\mathrm{T}$ cells transduced with these $\mathrm{T}$ cell receptors recognized autologous LCLs weakly, partially due to limited latent EBV antigen expression in LCLs. However, the tumor progression of a NPC cell line expressing LMP2 implanted into nude mice was significantly attenuated by LMP2 TCR transduced T cells (215). It was hypothesized that some of the transduced TCR $\alpha$ and $\beta$ chains might pair with the endogenous TCR $\beta$ and $\alpha$ chains of the $\mathrm{T}$ cells, which reduce the number of transduced TCR and thereby prevented efficient LCL recognition (216). To improve correct pairing of transduced TCR $\alpha$ and $\beta$ chains, chimeric TCRs were generated, where the variable domains of TCR $\alpha$ and $\beta$ chains from EBV specific $\mathrm{T}$ cell clones were fused to the corresponding mouse TCR constant regions (217). The stability of chimeric TCRs was further improved by introducing an additional disulfide bond between the $\alpha$ and $\beta$ chain of the murine TCR constant regions $(202,218)$. As a result, T cells transduced with a chimeric TCR recognizing LMP2 were able to kill up to half of co-incubated LMP2 positive cells in vitro and to suppress LMP2 expressing tumor cell growth in immune compromised mice [(202), Table 3]. Similar results were observed with a TCR recognizing EBV LMP1, and T cells transduced with LMP1 specific TCR doubled the survival of immune compromised mice challenged with LMP1 expressing tumor cells (203).

\section{EBV Specific Chimeric Antigen Receptor T Cell Therapy}

$\mathrm{T}$ cells expressing chimeric antigen receptors (CARs) targeting CD19, CD20, CD22 and CD30 were able to kill around 50\% of different $\mathrm{B}$ cell lymphomas in cell culture, and have provided spectacular results in clinical trials, with $60 \%$ of B cell lymphoma and leukemia patients in complete remission after treatment (219-223). However, significant adverse effects of cytokine release syndrome and neurotoxicity have also been observed due to the abundance of target cells, including both normal and malignant B cells after infusion of CAR-T cells (123). Further, deficiencies in humoral immune responses could be induced due to the persistent non-specific killing of $\mathrm{B}$ cells and predispose the patients for respiratory and gastrointestinal infections (224). To avoid the adverse effects of B cell antigen specific CAR-Ts, EBV specific CAR-Ts have been explored for treatment of NPC. LMP1 specific CAR-T cells could kill up to $70 \%$ of LMP1 overexpressing NPC cells in vitro, and intratumoral injection of anti-LMP1 CAR-T cells significantly reduced the growth of NPC tumor overexpressing LMP1 in immune compromised mice [(204, 205), Table 3]. Though it is questionable whether the LMP1 specific CAR-T cells could target the tumor cells in NPC patients where LMP1 expression is usually much lower, the results are encouraging. Clinical trials using LMP1 specific

TABLE 3 | Summary of EBV immune cell therapies.

\begin{tabular}{|c|c|c|c|}
\hline Platform & $\begin{array}{c}\text { Disease, clinical } \\
\text { trial/Animal } \\
\text { model }\end{array}$ & $\begin{array}{c}\text { Published } \\
\text { year }\end{array}$ & Results \\
\hline
\end{tabular}

\begin{abstract}
1. Adoptive T-cell therapy
Donor-derived EBV-specific T lymphocytes

EBV-specific cytotoxic T-lymphocyte (CTL) lines from donor

Donor-derived polyclonal CD4+ and CD8+ T-cell lines

Autologous EBV-specific CTL lines

Autologous EBV-specific CD8 and CD4 lymphocytes

Autologous EBV-specificcytotoxic T lymphocytes

Autologous EBV-specific cytotoxic T lymphocytes

Autologous EBV-specific cytotoxic T lymphocytes

Autologous EBV-specific cytotoxic T Iymphocytes

Autologous EBV-specific cytotoxic T lymphocytes targeting LMP2

2. EBV Specific T Cell Receptor (TCR) engineered T cell therapy Autologous CD8 and CD4 Lymphocytes expressing LMP2 specific TCR

Autologous CD8 and CD4 Lymphocytes expressing LMP1 specific TCR

NSG mouse NPC model NSG mouse tumor model
\end{abstract}

$\begin{array}{lll}\text { PTLD } & \text { I } & 1994 \\ \text { PTLD, HSCT } & \text { I } & 1995 \\ \text { PTLD, HSCT } & \text { । } & 1998 \\ \text { PTLD, SOT } & \text { । } & 1999 \\ \text { PTLD, SOT } & \text { । } & 2006 \\ \text { SOT } & \text { । } & 2002 \\ \text { NPC } & \text { I } & 2005 \\ \text { NPC } & \text { I/I } & 2010 \\ \text { NPC } & \text { ॥ } & 2014 \\ \text { Lymphoma } & \text { ॥ } & 2014\end{array}$

3. EBV Specific Chimeric Antigen Receptor (CAR) T cell therapy

CD8 and CD4 Lymphocytes Expressing LMP1 specific CAR NSG mouse

tumor model
Complete regression in 5/5 patients, but graft-versus-host disease developed (194).

Complete regression of immunoblastic lymphoma in 1/1 patients, EBV reactivation controlled in 3/3 patients without lymphoma (64). Complete regression of immunoblastic lymphoma in $2 / 2$ patients, EBV reactivation controlled in 6/6 patients without lymphoma (65). Significant regression of the PTLD in 1/1 patient (195).

Complete regression of liver PTLD in 1/1 patient, prevention of PTLD in 12/12 patients (196).

Decrease EBV load, prevention of PTLD in 7/7 patients (197).

Complete response in 4/10 patients and partial response in 2/10 patients (198).

Complete response in 7/15 patients and partial response in 3/15 patients (199).

Complete response in $3 / 35$ patients and partial response 22/35 patients (200).

Complete response in 11/21 patients and partial response 2/21 patients (201).

2015 Lysed LMP2+ NPC cells and inhibited tumor growth in a mouse model (202).

2018 Doubled the survival time of mice bearing tumor (203).
Killed $70 \%$ of LMP1 overexpressing NPC cells in vitro, and significantly reduced the growth of NPC tumor overexpressing LMP1 (204, 205). 
CAR-T cells for the treatment of NPC are underway, but no results have yet reported. EBV LMP2 is another promising target for treatment of EBV associated cancers.

\section{CONCLUSION}

EBV infects more than $95 \%$ of the human population, causes IM in $70 \%$ of adolescents and young adults in developed countries, accounts for $1.5 \%$ of all cancers worldwide and represent $1.8 \%$ of all cancer deaths. An EBV prophylactic vaccine holds great promise for prevention of EBV associated cancers such as BL, HL, PTLD, NPC, and GC, and would also be the most costeffective approach for the management of IM as well as EBV associated autoimmune disease such as MS. Though VLP, viral vector and mRNA platforms have been used for the development of an EBV prophylactic vaccine, the approach using recombinant EBV envelope proteins has made advancement the most. EBV envelope proteins including $\mathrm{gH} / \mathrm{gL}, \mathrm{gB}$, gp350 play key roles in EBV entry and infection of its target cells, and neutralizing antibodies elicited by each of these proteins have shown to prevent EBV infection of target cells, markedly decrease EBV titers in the blood of humanized mice, and prevent their death after challenge with lethal dose EBV. Recent studies demonstrated that immunization with the combination of recombinant $\mathrm{EBV} \mathrm{gH} / \mathrm{gL}$ and $\mathrm{gB}$ proteins markedly increased the EBV neutralizing activity compared to immunization with individual protein. These data suggest that the combination of EBV gH/gL, gB and gp350 could be an ideal EBV prophylactic vaccine that can elicit markedly high EBV neutralizing activity with the potential to induce sterilizing immunization, prevent primary EBV infection and therefore prevent EBV associated cancers as well IM and MS.

For patients with EBV-associated cancers, therapeutic EBV vaccines targeting latent proteins EBNA1, LMP2 and/or LMP1 are promising treatments. Though the current DC-based and viral vector EBV therapeutic vaccines have shown significant

\section{REFERENCES}

1. Cohen JI, Fauci AS, Varmus H, Nabel GJ. Epstein-Barr Virus: An Important Vaccine Target for Cancer Prevention. Sci Transl Med (2011) 3(107):107fs7. doi: 10.1126/scitranslmed.3002878

2. Vetsika EK, Callan M. Infectious Mononucleosis and Epstein-Barr Virus. Expert Rev Mol Med (2004) 6(23):1-16. doi: 10.1017/S1462399404008440

3. Cohen JI, Mocarski ES, Raab-Traub N, Corey L, Nabel GJ. The Need and Challenges for Development of an Epstein-Barr Virus Vaccine. Vaccine (2013) 31 Suppl 2:B194-6. doi: 10.1016/j.vaccine.2012.09.041

4. Luzuriaga K, Sullivan JL. Infectious Mononucleosis. N Engl J Med (2010) 362 (21):1993-2000. doi: 10.1056/NEJMcp1001116

5. Hallee TJ, Evans AS, Niederman JC, Brooks CM, Voegtly j H. Infectious Mononucleosis at the United States Military Academy. A Prospective Study of a Single Class Over Four Years. Yale J Biol Med (1974) 47(3):182-95.

6. Rea TD, Russo JE, Katon W, Ashley RL, Buchwald DS. Prospective Study of the Natural History of Infectious Mononucleosis Caused by Epstein-Barr Virus. J Am Board Fam Pract (2001) 14(4):234-42.

7. Cohen JI. Vaccine Development for Epstein-Barr Virus. Adv Exp Med Biol (2018) 1045:477-93. doi: 10.1007/978-981-10-7230-7_22 limitations, different vaccine platforms targeting both latent and lytic envelope proteins including EBNA1, LMP1/LMP2, gp350, $\mathrm{gH} / \mathrm{gL}$ and $\mathrm{gB}$ simultaneously can be explored to improve efficacy. Immune cell therapies for EBV-associated cancers have emerged as another highly promising treatment. ACT has demonstrated to cure and prevent PTLD, and has shown to be highly effective in the treatment of NPC and HL by targeting latent proteins EBNA1, LMP1/LMP2. To further improve efficacy and minimize adverse effects, EBV specific CAR-T and TCR engineered $\mathrm{T}$ cell therapies targeting EBV latent protein LMP1, LMP2 and/or EBNA1 have been developed, with the goal of specific killing of EBV+ cancer cells highly efficiently.

\section{AUTHOR CONTRIBUTIONS}

$\mathrm{XC}$ prepared the manuscript draft, CMS provided comments to the text and figures, read and approved the final manuscript. All authors contributed to the article and approved the submitted version.

\section{FUNDING}

This research was supported in part by the Intramural Research Program of the National Cancer Institute, National Institutes of Health. This research was also supported by the Dean's Research and Education Endowment Fund from Uniformed Services University of the Health Sciences (USUHS). USUHS had no involvement in design of study, data analysis or interpretation, nor manuscript preparation or study publication.

\section{ACKNOWLEDGMENTS}

The authors thank Dr. James Gulley at CCR, NCI, NIH for reviewing the manuscript.

8. Neparidze N, Lacy J. Malignancies Associated With Epstein-Barr Virus: Pathobiology, Clinical Features, and Evolving Treatments. Clin Adv Hematol Oncol (2014) 12(6):358-71.

9. Fukayama M. Epstein-Barr Virus and Gastric Carcinoma. Pathol Int (2010) 60(5):337-50. doi: 10.1111/j.1440-1827.2010.02533.x

10. Parkin DM. The Global Health Burden of Infection-Associated Cancers in the Year 2002. Int J Cancer (2006) 118(12):3030-44. doi: 10.1002/ijc.21731

11. Hjalgrim H, Askling J, Sorensen P, Madsen M, Rosdahl N, Storm HH, et al. Risk of Hodgkin's Disease and Other Cancers After Infectious Mononucleosis. J Natl Cancer Inst (2000) 92(18):1522-8. doi: 10.1093/ jnci/92.18.1522

12. Dharnidharka VR. Comprehensive Review of Post-Organ Transplant Hematologic Cancers. Am J Transplant (2018) 18(3):537-49. doi: 10.1111/ ajt.14603

13. Al-Mansour Z, Nelson BP, Evens AM. Post-Transplant Lymphoproliferative Disease (PTLD): Risk Factors, Diagnosis, and Current Treatment Strategies. Curr Hematol Malig Rep (2013) 8(3):173-83. doi: 10.1007/s11899-0130162-5

14. AlDabbagh MA, Gitman MR, Kumar D, Humar A, Rotstein C, Husain S. The Role of Antiviral Prophylaxis for the Prevention of Epstein-Barr VirusAssociated Posttransplant Lymphoproliferative Disease in Solid Organ 
Transplant Recipients: A Systematic Review. Am J Transplant (2017) 17 (3):770-81. doi: 10.1111/ajt.14020

15. Kimura H, Ito Y, Kawabe S, Gotoh K, Takahashi Y, Kojima S, et al. EBV-Associated T/NK-Cell Lymphoproliferative Diseases in Nonimmunocompromised Hosts: Prospective Analysis of 108 Cases. Blood (2012) 119(3):673-86. doi: 10.1182/ blood-2011-10-381921

16. Song SY, Kim WS, Ko YH, Kim K, Lee MH, Park K. Aggressive Natural Killer Cell Leukemia: Clinical Features and Treatment Outcome. Haematologica (2002) 87(12):1343-5.

17. Iezzoni JC, Gaffey MJ, Weiss LM. The Role of Epstein-Barr Virus in Lymphoepithelioma-Like Carcinomas. Am J Clin Pathol (1995) 103 (3):308-15. doi: 10.1093/ajcp/103.3.308

18. Villegas E, Santiago O, Sorlozano A, Gutierrez J. New Strategies and Patent Therapeutics in EBV-Associated Diseases. Mini Rev Med Chem (2010) 10 (10):914-27. doi: 10.2174/138955710792007150

19. Matar CG, Jacobs NT, Speck SH, Lamb TJ, Moormann AM. Does EBV Alter the Pathogenesis of Malaria? Parasite Immunol (2015) 37(9):433-45. doi: 10.1111/pim.12212

20. Imai K, Kotani T, Tsuda H, Kobayashi T, Ushida T, Moriyama $\mathrm{Y}$, et al. Determination of the Cytokine Levels in Fetal Pleural Effusion and Their Association With Fetal/Neonatal Findings. Cytokine (2020) 127:154945. doi: 10.1016/j.cyto.2019.154945

21. Dasari V, Sinha D, Neller MA, Smith C, Khanna R. Prophylactic and Therapeutic Strategies for Epstein-Barr Virus-Associated Diseases: Emerging Strategies for Clinical Development. Expert Rev Vaccines (2019) 18(5):457-74. doi: 10.1080/14760584.2019.1605906

22. Farrell PJ. Epstein-Barr Virus and Cancer. Annu Rev Pathol (2019) 14:29-53. doi: 10.1146/annurev-pathmechdis-012418-013023

23. Niederman JC, McCollum RW, Henle G, Henle W. Infectious Mononucleosis. Clinical Manifestations in Relation to EB Virus Antibodies. JAMA (1968) 203 (3):205-9. doi: 10.1001/jama.1968.03140030037009

24. Connolly SA, Jackson JO, Jardetzky TS, Longnecker R. Fusing Structure and Function: A Structural View of the Herpesvirus Entry Machinery. Nat Rev Microbiol (2011) 9(5):369-81. doi: 10.1038/nrmicro2548

25. Hutt-Fletcher LM. Epstein-Barr Virus Entry. J Virol (2007) 81(15):7825-32. doi: 10.1128/JVI.00445-07

26. Shannon-Lowe C, Rowe M. Epstein Barr Virus Entry; Kissing and Conjugation. Curr Opin Virol (2014) 4:78-84. doi: 10.1016/j.coviro.2013.12.001

27. Neuhierl B, Feederle R, Hammerschmidt W, Delecluse HJ. Glycoprotein Gp110 of Epstein-Barr Virus Determines Viral Tropism and Efficiency of Infection. Proc Natl Acad Sci U.S.A. (2002) 99(23):15036-41. doi: 10.1073/ pnas. 232381299

28. Heldwein EE, Krummenacher C. Entry of Herpesviruses Into Mammalian Cells. Cell Mol Life Sci (2008) 65(11):1653-68. doi: 10.1007/s00018-008-7570-z

29. Jiang R, Gu X, Nathan CO, Hutt-Fletcher L. Laser-Capture Microdissection of Oropharyngeal Epithelium Indicates Restriction of Epstein-Barr Virus Receptor/CD21 mRNA to Tonsil Epithelial Cells. J Oral Pathol Med (2008) 37(10):626-33. doi: 10.1111/j.1600-0714.2008.00681.x

30. Birkenbach M, Tong X, Bradbury LE, Tedder TF, Kieff E. Characterization of an Epstein-Barr Virus Receptor on Human Epithelial Cells. J Exp Med (1992) 176(5):1405-14. doi: 10.1084/jem.176.5.1405

31. Maruo S, Yang L, Takada K. Roles of Epstein-Barr Virus Glycoproteins Gp350 and Gp25 in the Infection of Human Epithelial Cells. J Gen Virol (2001) 82(Pt 10):2373-83. doi: 10.1099/0022-1317-82-10-2373

32. Fingeroth JD, Diamond ME, Sage DR, Hayman J, Yates JL. CD21Dependent Infection of an Epithelial Cell Line, 293, by Epstein-Barr Virus. J Virol (1999) 73(3):2115-25. doi: 10.1128/JVI.73.3.2115-2125.1999

33. Hutt-Fletcher LM. Epstein-Barr Virus Replicating in Epithelial Cells. Proc Natl Acad Sci U.S.A. (2014) 111(46):16242-3. doi: 10.1073/pnas.1418974111

34. Tsao SW, Tsang CM, Pang PS, Zhang G, Chen H, Lo KW. The Biology of EBV Infection in Human Epithelial Cells. Semin Cancer Biol (2012) 22 (2):137-43. doi: 10.1016/j.semcancer.2012.02.004

35. Li QX, Young LS, Niedobitek G, Dawson CW, Birkenbach M, Wang F, et al. Epstein-Barr Virus Infection and Replication in a Human Epithelial Cell System. Nature (1992) 356(6367):347-50. doi: 10.1038/356347a0

36. Backovic M, Longnecker R, Jardetzky TS. Structure of a Trimeric Variant of the Epstein-Barr Virus Glycoprotein B. Proc Natl Acad Sci USA (2009) 106 (8):2880-5. doi: 10.1073/pnas.0810530106
37. Chesnokova LS, Jiang R, Hutt-Fletcher LM. Viral Entry. Curr Top Microbiol Immunol (2015) 391:221-35. doi: 10.1007/978-3-319-22834-1_7

38. Hislop AD, Taylor GS, Sauce D, Rickinson AB. Cellular Responses to Viral Infection in Humans: Lessons From Epstein-Barr Virus. Annu Rev Immunol (2007) 25:587-617. doi: 10.1146/annurev.immunol.25.022106.141553

39. Rickinson $\mathrm{AB}$, Long HM, Palendira U, Munz C, Hislop AD. Cellular Immune Controls Over Epstein-Barr Virus Infection: New Lessons From the Clinic and the Laboratory. Trends Immunol (2014) 35(4):159-69. doi: 10.1016/j.it.2014.01.003

40. Taylor GS, Long HM, Brooks JM, Rickinson AB, Hislop AD. The Immunology of Epstein-Barr Virus-Induced Disease. Annu Rev Immunol (2015) 33:787-821. doi: 10.1146/annurev-immunol-032414-112326

41. Shannon-Lowe C, Rickinson A. The Global Landscape of EBV-Associated Tumors. Front Oncol (2019) 9:713. doi: 10.3389/fonc.2019.00713

42. Ayee R, Ofori MEO, Wright E, Quaye O. Epstein Barr Virus Associated Lymphomas and Epithelia Cancers in Humans. J Cancer (2020) 11(7):173750. doi: $10.7150 /$ jca.37282

43. Fugl A, Andersen CL. Epstein-Barr Virus and Its Association With Disease a Review of Relevance to General Practice. BMC Fam Pract (2019) 20(1):62. doi: 10.1186/s12875-019-0954-3

44. Dunmire SK, Verghese PS, Balfour HHJr. Primary Epstein-Barr Virus Infection. J Clin Virol (2018) 102:84-92. doi: 10.1016/j.jcv.2018.03.001

45. Chandran B, Hutt-Fletcher L. Gammaherpesviruses Entry and Early Events During Infection. In: A Arvin, G Campadelli-Fiume, E Mocarski, PS Moore, B Roizman, R Whitley, et al. editors. Human Herpesviruses: Biology, Therapy, and Immunoprophylaxis. Cambridge University Press (2007).

46. Tattevin P, Le Tulzo Y, Minjolle S, Person A, Chapplain JM, Arvieux C, et al. Increasing Incidence of Severe Epstein-Barr Virus-Related Infectious Mononucleosis: Surveillance Study. J Clin Microbiol (2006) 44(5):1873-4. doi: 10.1128/JCM.44.5.1873-1874.2006

47. Rostgaard K, Balfour HHJr., Jarrett R, Erikstrup C, Pedersen O, Ullum H, et al. Primary Epstein-Barr Virus Infection With and Without Infectious Mononucleosis. PloS One (2019) 14(12):e0226436. doi: 10.1371/ journal.pone.0226436

48. Jayasooriya S, de Silva TI, Njie-jobe J, Sanyang C, Leese AM, Bell AI, et al. Early Virological and Immunological Events in Asymptomatic Epstein-Barr Virus Infection in African Children. PloS Pathog (2015) 11(3):e1004746. doi: 10.1371/journal.ppat.1004746

49. Abbott RJ, Pachnio A, Pedroza-Pacheco I, Leese AM, Begum J, Long HM, et al. Asymptomatic Primary Infection With Epstein-Barr Virus: Observations on Young Adult Cases. J Virol (2017) 91(21). doi: 10.1128/ JVI.00382-17

50. Odame J, Robinson J, Khodai-Booran N, Yeung S, Mazzulli T, Stephens D, et al. Correlates of Illness Severity in Infectious Mononucleosis. Can J Infect Dis Med Microbiol (2014) 25(5):277-80. doi: 10.1155/2014/514164

51. Williams H, Macsween K, McAulay K, Higgins C, Harrison N, Swerdlow A, et al. Analysis of Immune Activation and Clinical Events in Acute Infectious Mononucleosis. J Infect Dis (2004) 190(1):63-71. doi: 10.1086/421276

52. Chatterjee B, Leung CS, Munz C. Animal Models of Epstein Barr Virus Infection. J Immunol Methods (2014) 410:80-7. doi: 10.1016/ j.jim.2014.04.009

53. Glynn FJ, Mackle T, Kinsella J. Upper Airway Obstruction in Infectious Mononucleosis. Eur J Emerg Med (2007) 14(1):41-2. doi: 10.1097/ 01.mej.0000224431.36376.71

54. Elgui de Oliveira D, Muller-Coan BG, Pagano JS. Viral Carcinogenesis Beyond Malignant Transformation: EBV in the Progression of Human Cancers. Trends Microbiol (2016) 24(8):649-64. doi: 10.1016/ j.tim.2016.03.008

55. Chen XZ, Chen H, Castro FA, Hu JK, Brenner H. Epstein-Barr Virus Infection and Gastric Cancer: A Systematic Review. Med (Baltimore) (2015) 94(20):e792. doi: 10.1097/MD.0000000000000792

56. Lee JH, Kim SH, Han SH, An JS, Lee ES, Kim YS. Clinicopathological and Molecular Characteristics of Epstein-Barr Virus-Associated Gastric Carcinoma: A Meta-Analysis. J Gastroenterol Hepatol (2009) 24(3):35465. doi: 10.1111/j.1440-1746.2009.05775.x

57. Mawson AR, Majumdar S. Malaria, Epstein-Barr Virus Infection and the Pathogenesis of Burkitt's Lymphoma. Int J Cancer (2017) 141(9):1849-55. doi: 10.1002/ijc.30885 
58. Rochford R, Moormann AM. Burkitt's Lymphoma. Curr Top Microbiol Immunol (2015) 390(Pt 1):267-85. doi: 10.1007/978-3-319-22822-8_11

59. Bornkamm GW. Epstein-Barr Virus and the Pathogenesis of Burkitt's Lymphoma: More Questions Than Answers. Int J Cancer (2009) 124 (8):1745-55. doi: 10.1002/ijc.24223

60. Shanbhag S, Ambinder RF. Hodgkin Lymphoma: A Review and Update on Recent Progress. CA Cancer J Clin (2018) 68(2):116-32. doi: 10.3322/ caac. 21438

61. Ambinder RF. Epstein-Barr Virus and Hodgkin Lymphoma. Hematol Am Soc Hematol Educ Program (2007), 204-9. doi: 10.1182/asheducation2007.1.204

62. Weiss LM, Movahed LA, Warnke RA, Sklar J. Detection of Epstein-Barr Viral Genomes in Reed-Sternberg Cells of Hodgkin's Disease. N Engl J Med (1989) 320(8):502-6. doi: 10.1056/NEJM198902233200806

63. Anagnostopoulos I, Herbst H, Niedobitek G, Stein H. Demonstration of Monoclonal EBV Genomes in Hodgkin's Disease and Ki-1-Positive Anaplastic Large Cell Lymphoma by Combined Southern Blot and in Situ Hybridization. Blood (1989) 74(2):810-6. doi: 10.1182/ blood.V74.2.810.810

64. Rooney CM, Smith CA, Ng CY, Loftin S, Li C, Krance RA, et al. Use of GeneModified Virus-Specific T Lymphocytes to Control Epstein-Barr-VirusRelated Lymphoproliferation. Lancet (1995) 345(8941):9-13. doi: 10.1016/ S0140-6736(95)91150-2

65. Rooney CM, Smith CA, Ng CY, Loftin SK, Sixbey JW, Gan Y, et al. Infusion of Cytotoxic T Cells for the Prevention and Treatment of Epstein-Barr Virus-Induced Lymphoma in Allogeneic Transplant Recipients. Blood (1998) 92(5):1549-55. doi: 10.1182/blood.V92.5.1549.417k32_1549_1555

66. Heslop HE, Ng CY, Li C, Smith CA, Loftin SK, Krance RA, et al. Long-Term Restoration of Immunity Against Epstein-Barr Virus Infection by Adoptive Transfer of Gene-Modified Virus-Specific T Lymphocytes. Nat Med (1996) 2 (5):551-5. doi: 10.1038/nm0596-551

67. Heslop HE, Slobod KS, Pule MA, Hale GA, Rousseau A, Smith CA, et al. Long-Term Outcome of EBV-Specific T-Cell Infusions to Prevent or Treat EBV-Related Lymphoproliferative Disease in Transplant Recipients. Blood (2010) 115(5):925-35. doi: 10.1182/blood-2009-08-239186

68. Gottschalk S, Rooney CM. Adoptive T-Cell Immunotherapy. Curr Top Microbiol Immunol (2015) 391:427-54. doi: 10.1007/978-3-319-22834-1_15

69. Sashihara J, Hoshino Y, Bowman JJ, Krogmann T, Burbelo PD, Coffield VM, et al. Soluble Rhesus Lymphocryptovirus Gp350 Protects Against Infection and Reduces Viral Loads in Animals That Become Infected With Virus After Challenge. PloS Pathog (2011) 7(10):e1002308. doi: 10.1371/ journal.ppat.1002308

70. Morgan AJ, Epstein MA, North JR. Comparative Immunogenicity Studies on Epstein-Barr Virus Membrane Antigen (MA) Gp340 With Novel Adjuvants in Mice, Rabbits, and Cotton-Top Tamarins. J Med Virol (1984) 13(3):281-92. doi: 10.1002/jmv.1890130310

71. Morgan AJ, Allison AC, Finerty S, Scullion FT, Byars NE, Epstein MA. Validation of a First-Generation Epstein-Barr Virus Vaccine Preparation Suitable for Human Use. J Med Virol (1989) 29(1):74-8. doi: 10.1002/ jmv. 1890290114

72. Finerty S, Tarlton J, Mackett M, Conway M, Arrand JR, Watkins PE, et al. Protective Immunization Against Epstein-Barr Virus-Induced Disease in Cottontop Tamarins Using the Virus Envelope Glycoprotein Gp340 Produced From a Bovine Papillomavirus Expression Vector. J Gen Virol (1992) 73( Pt 2):449-53. doi: 10.1099/0022-1317-73-2-449

73. Cox C, Naylor BA, Mackett M, Arrand JR, Griffin BE, Wedderburn N. Immunization of Common Marmosets With Epstein-Barr Virus (EBV) Envelope Glycoprotein Gp340: Effect on Viral Shedding Following EBV Challenge. J Med Virol (1998) 55(4):255-61. doi: 10.1002/(SICI)1096-9071 (199808)55:4<255::AID-JMV1>3.0.CO;2-\#

74. Mackett M, Cox C, Pepper SD, Lees JF, Naylor BA, Wedderburn N, et al. Immunisation of Common Marmosets With Vaccinia Virus Expressing Epstein-Barr Virus (EBV) Gp340 and Challenge With EBV. J Med Virol (1996) 50(3):263-71. doi: 10.1002/(SICI)1096-9071(199611)50:3<263::AIDJMV9>3.0.CO;2-7

75. Ragot T, Finerty S, Watkins PE, Perricaudet M, Morgan AJ. ReplicationDefective Recombinant Adenovirus Expressing the Epstein-Barr Virus (EBV) Envelope Glycoprotein Gp340/220 Induces Protective Immunity
Against EBV-Induced Lymphomas in the Cottontop Tamarin. J Gen Virol (1993) 74( Pt 3):501-7. doi: 10.1099/0022-1317-74-3-501

76. Morgan AJ, Mackett M, Finerty S, Arrand JR, Scullion FT, Epstein MA. Recombinant Vaccinia Virus Expressing Epstein-Barr Virus Glycoprotein Gp340 Protects Cottontop Tamarins Against EB Virus-Induced Malignant Lymphomas. J Med Virol (1988) 25(2):189-95. doi: 10.1002/jmv.1890250209

77. Yajima M, Imadome K, Nakagawa A, Watanabe S, Terashima K, Nakamura $\mathrm{H}$, et al. A New Humanized Mouse Model of Epstein-Barr Virus Infection That Reproduces Persistent Infection, Lymphoproliferative Disorder, and Cell-Mediated and Humoral Immune Responses. J Infect Dis (2008) 198 (5):673-82. doi: 10.1086/590502

78. Sato K, Misawa N, Nie C, Satou Y, Iwakiri D, Matsuoka M, et al. A Novel Animal Model of Epstein-Barr Virus-Associated Hemophagocytic Lymphohistiocytosis in Humanized Mice. Blood (2011) 117(21):5663-73. doi: 10.1182/blood-2010-09-305979

79. Swerdlow SH, Campo E, Pileri SA, Harris NL, Stein H, Siebert R, et al. The 2016 Revision of the World Health Organization Classification of Lymphoid Neoplasms. Blood (2016) 127(20):2375-90. doi: 10.1182/blood-2016-01643569

80. Lenze D, Leoncini L, Hummel M, Volinia S, Liu CG, Amato T, et al. The Different Epidemiologic Subtypes of Burkitt Lymphoma Share a Homogenous Micro RNA Profile Distinct From Diffuse Large B-Cell Lymphoma. Leukemia (2011) 25(12):1869-76. doi: 10.1038/leu.2011.156

81. Shannon-Lowe C, Rickinson AB, Bell AI. Epstein-Barr Virus-Associated Lymphomas. Philos Trans R Soc Lond B Biol Sci (2017) 372(1732). doi: 10.1098/rstb.2016.0271

82. Queiroga EM, Gualco G, Weiss LM, Dittmer DP, Araujo I, Klumb CE, et al. Burkitt Lymphoma in Brazil is Characterized by Geographically Distinct Clinicopathologic Features. Am J Clin Pathol (2008) 130(6):946-56. doi: 10.1309/AJCP64YOHAWLUMPK

83. Gloghini A, Dolcetti R, Carbone A. Lymphomas Occurring Specifically in HIV-Infected Patients: From Pathogenesis to Pathology. Semin Cancer Biol (2013) 23(6):457-67. doi: 10.1016/j.semcancer.2013.08.004

84. Magrath I. Epidemiology: Clues to the Pathogenesis of Burkitt Lymphoma. Br J Haematol (2012) 156(6):744-56. doi: 10.1111/j.1365-2141.2011.09013.x

85. Allday MJ. How Does Epstein-Barr Virus (EBV) Complement the Activation of Myc in the Pathogenesis of Burkitt's Lymphoma? Semin Cancer Biol (2009) 19(6):366-76. doi: 10.1016/j.semcancer.2009.07.007

86. Tsao SW, Tsang CM, Lo KW. Epstein-Barr Virus Infection and Nasopharyngeal Carcinoma. Philos Trans R Soc Lond B Biol Sci (2017) 372(1732). doi: 10.1098/rstb.2016.0270

87. Kirchmaier AL, Sugden B. Dominant-Negative Inhibitors of EBNA-1 of EpsteinBarr Virus. J Virol (1997) 71(3):1766-75. doi: 10.1128/jvi.71.3.1766-1775.1997

88. Thorley-Lawson D, Deitsch KW, Duca KA, Torgbor C. The Link Between Plasmodium Falciparum Malaria and Endemic Burkitt's Lymphoma-New Insight Into a 50-Year-Old Enigma. PloS Pathog (2016) 12(1):e1005331. doi: 10.1371/journal.ppat.1005331

89. Carbone A, Cesarman E, Spina M, Gloghini A, Schulz TF. HIV-Associated Lymphomas and Gamma-Herpesviruses. Blood (2009) 113(6):1213-24. doi: 10.1182/blood-2008-09-180315

90. Pallesen G, Hamilton-Dutoit SJ, Rowe M, Young LS. Expression of EpsteinBarr Virus Latent Gene Products in Tumour Cells of Hodgkin's Disease. Lancet (1991) 337(8737):320-2. doi: 10.1016/0140-6736(91)90943-J

91. Glaser SL, Lin RJ, Stewart SL, Ambinder RF, Jarrett RF, Brousset P, et al. Epstein-Barr Virus-Associated Hodgkin's Disease: Epidemiologic Characteristics in International Data. Int J Cancer (1997) 70(4):375-82. doi: 10.1002/(SICI)1097-0215(19970207)70:4<375::AID-IJC1>3.0.CO;2-T

92. Vrzalikova K, Ibrahim M, Nagy E, Vockerodt M, Perry T, Wei W, et al. CoExpression of the Epstein-Barr Virus-Encoded Latent Membrane Proteins and the Pathogenesis of Classic Hodgkin Lymphoma. Cancers (Basel) (2018) 10(9). doi: $10.3390 /$ cancers 10090285

93. Kuppers R, Kanzler H, Hansmann ML, Rajewsky K. Single Cell Analysis of Hodgkin/Reed-Sternberg Cells. Ann Oncol (1996) 7 Suppl 4:27-30. doi: 10.1093/annonc/7.suppl_4.S27

94. Kanzler H, Kuppers R, Hansmann ML, Rajewsky K. Hodgkin and ReedSternberg Cells in Hodgkin's Disease Represent the Outgrowth of a Dominant Tumor Clone Derived From (Crippled) Germinal Center B Cells. J Exp Med (1996) 184(4):1495-505. doi: 10.1084/jem.184.4.1495 
95. Kuppers R, Rajewsky K, Zhao M, Simons G, Laumann R, Fischer R, et al. Hodgkin's Disease: Clonal Ig Gene Rearrangements in Hodgkin and ReedSternberg Cells Picked From Histological Sections. Ann N Y Acad Sci (1995) 764:523-4. doi: 10.1111/j.1749-6632.1995.tb55877.x

96. Bargou RC, Emmerich F, Krappmann D, Bommert K, Mapara MY, Arnold W, et al. Constitutive Nuclear factor-kappaB-RelA Activation is Required for Proliferation and Survival of Hodgkin's Disease Tumor Cells. J Clin Invest (1997) 100(12):2961-9. doi: 10.1172/JCI119849

97. Dutton A, Reynolds GM, Dawson CW, Young LS, Murray PG. Constitutive Activation of Phosphatidyl-Inositide 3 Kinase Contributes to the Survival of Hodgkin's Lymphoma Cells Through a Mechanism Involving Akt Kinase and mTOR. J Pathol (2005) 205(4):498-506. doi: 10.1002/path.1725

98. Gires O, Kohlhuber F, Kilger E, Baumann M, Kieser A, Kaiser C, et al. Latent Membrane Protein 1 of Epstein-Barr Virus Interacts With JAK3 and Activates STAT Proteins. EMBO J (1999) 18(11):3064-73. doi: 10.1093/ emboj/18.11.3064

99. Huen DS, Henderson SA, Croom-Carter D, Rowe M. The Epstein-Barr Virus Latent Membrane Protein-1 (LMP1) Mediates Activation of NFKappa B and Cell Surface Phenotype via Two Effector Regions in Its Carboxy-Terminal Cytoplasmic Domain. Oncogene (1995) 10(3):549-60.

100. Holtick U, Vockerodt M, Pinkert D, Schoof N, Sturzenhofecker B, Kussebi N, et al. STAT3 is Essential for Hodgkin Lymphoma Cell Proliferation and is a Target of Tyrphostin AG17 Which Confers Sensitization for Apoptosis. Leukemia (2005) 19(6):936-44. doi: 10.1038/sj.leu.2403750

101. Eliopoulos AG, Young LS. Activation of the Cjun N-Terminal Kinase (JNK) Pathway by the Epstein-Barr Virus-Encoded Latent Membrane Protein 1 (LMP1). Oncogene (1998) 16(13):1731-42. doi: 10.1038/sj.onc.1201694

102. Laherty CD, Hu HM, Opipari AW, Wang F, Dixit VM. The Epstein-Barr Virus LMP1 Gene Product Induces A20 Zinc Finger Protein Expression by Activating Nuclear Factor Kappa B. J Biol Chem (1992) 267(34):24157-60. doi: 10.1016/S0021-9258(18)35741-7

103. Kieser A, Kilger E, Gires O, Ueffing M, Kolch W, Hammerschmidt W. Epstein-Barr Virus Latent Membrane Protein-1 Triggers AP-1 Activity via the C-Jun N-Terminal Kinase Cascade. EMBO J (1997) 16(21):6478-85. doi: 10.1093/emboj/16.21.6478

104. Finke J, Fritzen R, Ternes P, Trivedi P, Bross KJ, Lange W, et al. Expression of Bcl-2 in Burkitt's Lymphoma Cell Lines: Induction by Latent Epstein-Barr Virus Genes. Blood (1992) 80(2):459-69. doi: 10.1182/blood.V80.2.459.459

105. Henderson S, Rowe M, Gregory C, Croom-Carter D, Wang F, Longnecker R, et al. Induction of Bcl-2 Expression by Epstein-Barr Virus Latent Membrane Protein 1 Protects Infected B Cells From Programmed Cell Death. Cell (1991) 65(7):1107-15. doi: 10.1016/0092-8674(91)90007-L

106. Wang S, Rowe M, Lundgren E. Expression of the Epstein Barr Virus Transforming Protein LMP1 Causes a Rapid and Transient Stimulation of the Bcl-2 Homologue Mcl-1 Levels in B-Cell Lines. Cancer Res (1996) 56 (20):4610-3.

107. Caldwell RG, Brown RC, Longnecker R. Epstein-Barr Virus LMP2A-Induced B-Cell Survival in Two Unique Classes of EmuLMP2A Transgenic Mice. J Virol (2000) 74(3):1101-13. doi: 10.1128/JVI.74.3.1101-1113.2000

108. Fukuda M, Longnecker R. Epstein-Barr Virus Latent Membrane Protein 2A Mediates Transformation Through Constitutive Activation of the Ras/PI3K/Akt Pathway. J Virol (2007) 81(17):9299-306. doi: 10.1128/JVI.00537-07

109. Moody CA, Scott RS, Amirghahari N, Nathan CO, Young LS, Dawson CW, et al. Modulation of the Cell Growth Regulator mTOR by Epstein-Barr Virus-Encoded LMP2A. J Virol (2005) 79(9):5499-506. doi: 10.1128/ JVI.79.9.5499-5506.2005

110. Caldwell RG, Wilson JB, Anderson SJ, Longnecker R. Epstein-Barr Virus LMP2A Drives B Cell Development and Survival in the Absence of Normal B Cell Receptor Signals. Immunity (1998) 9(3):405-11. doi: 10.1016/S10747613(00)80623-8

111. Merchant M, Swart R, Katzman RB, Ikeda M, Ikeda A, Longnecker R, et al. The Effects of the Epstein-Barr Virus Latent Membrane Protein 2A on B Cell Function. Int Rev Immunol (2001) 20(6):805-35. doi: 10.3109/ 08830180109045591

112. Chaganti S, Bell AI, Pastor NB, Milner AE, Drayson M, Gordon J, et al. Epstein-Barr Virus Infection In Vitro can Rescue Germinal Center B Cells With Inactivated Immunoglobulin Genes. Blood (2005) 106(13):4249-52. doi: 10.1182/blood-2005-06-2327
113. Bechtel D, Kurth J, Unkel C, Kuppers R. Transformation of BCR-Deficient Germinal-Center B Cells by EBV Supports a Major Role of the Virus in the Pathogenesis of Hodgkin and Posttransplantation Lymphomas. Blood (2005) 106(13):4345-50. doi: 10.1182/blood-2005-06-2342

114. Mancao C, Altmann M, Jungnickel B, Hammerschmidt W. Rescue of "Crippled" Germinal Center B Cells From Apoptosis by Epstein-Barr Virus. Blood (2005) 106(13):4339-44. doi: 10.1182/blood-2005-06-2341

115. Mancao C, Hammerschmidt W. Epstein-Barr Virus Latent Membrane Protein 2A is a B-Cell Receptor Mimic and Essential for B-Cell Survival. Blood (2007) 110(10):3715-21. doi: 10.1182/blood-2007-05-090142

116. Portis T, Dyck P, Longnecker R. Epstein-Barr Virus (EBV) LMP2A Induces Alterations in Gene Transcription Similar to Those Observed in ReedSternberg Cells of Hodgkin Lymphoma. Blood (2003) 102(12):4166-78. doi: 10.1182/blood-2003-04-1018

117. Vockerodt M, Wei W, Nagy E, Prouzova Z, Schrader A, Kube D, et al. Suppression of the LMP2A Target Gene, EGR-1, Protects Hodgkin's Lymphoma Cells From Entry to the EBV Lytic Cycle. J Pathol (2013) 230 (4):399-409. doi: 10.1002/path.4198

118. Kim HJ, Ko YH, Kim JE, Lee SS, Lee H, Park G, et al. Epstein-Barr VirusAssociated Lymphoproliferative Disorders: Review and Update on 2016 WHO Classification. J Pathol Transl Med (2017) 51(4):352-8. doi: 10.4132/jptm.2017.03.15

119. Green M. Management of Epstein-Barr Virus-Induced Post-Transplant Lymphoproliferative Disease in Recipients of Solid Organ Transplantation. Am J Transplant (2001) 1(2):103-8.

120. Nijland ML, Kersten MJ, Pals ST, Bemelman FJ, Ten Berge IJ. Epstein-Barr Virus-Positive Posttransplant Lymphoproliferative Disease After Solid Organ Transplantation: Pathogenesis, Clinical Manifestations, Diagnosis, and Management. Transplant Direct (2016) 2(1):e48. doi: 10.1097/ TXD.0000000000000557

121. Stojanova J, Caillard S, Rousseau A, Marquet P. Post-Transplant Lymphoproliferative Disease (PTLD): Pharmacological, Virological and Other Determinants. Pharmacol Res (2011) 63(1):1-7. doi: 10.1016/ j.phrs.2010.10.016

122. Snow AL, Martinez OM. Epstein-Barr Virus: Evasive Maneuvers in the Development of PTLD. Am J Transplant (2007) 7(2):271-7. doi: 10.1111/ j.1600-6143.2006.01650.x

123. Guedan S, Ruella M, June CH. Emerging Cellular Therapies for Cancer. Annu Rev Immunol (2019) 37:145-71. doi: 10.1146/annurev-immunol042718-041407

124. Carle LN, Ko CC, Castle JT. Nasopharyngeal Carcinoma. Head Neck Pathol (2012) 6(3):364-8. doi: 10.1007/s12105-012-0333-z

125. Yu MC, Yuan JM. Epidemiology of Nasopharyngeal Carcinoma. Semin Cancer Biol (2002) 12(6):421-9. doi: 10.1016/S1044579X02000858

126. Chang ET, Adami HO. The Enigmatic Epidemiology of Nasopharyngeal Carcinoma. Cancer Epidemiol Biomarkers Prev (2006) 15(10):1765-77. doi: 10.1158/1055-9965.EPI-06-0353

127. Micheau C, Rilke F, Pilotti S. Proposal for a New Histopathological Classification of the Carcinomas of the Nasopharynx. Tumori (1978) 64 (5):513-8. doi: 10.1177/030089167806400509

128. Yoshizaki T, Kondo S, Wakisaka N, Murono S, Endo K, Sugimoto H, et al. Pathogenic Role of Epstein-Barr Virus Latent Membrane Protein-1 in the Development of Nasopharyngeal Carcinoma. Cancer Lett (2013) 337(1):1-7. doi: 10.1016/j.canlet.2013.05.018

129. Banko AV, Lazarevic IB, Folic MM, Djukic VB, Cirkovic AM, Karalic DZ, et al. Characterization of the Variability of Epstein-Barr Virus Genes in Nasopharyngeal Biopsies: Potential Predictors for Carcinoma Progression. PloS One (2016) 11(4):e0153498. doi: 10.1371/journal.pone.0153498

130. Raab-Traub N. Nasopharyngeal Carcinoma: An Evolving Role for the Epstein-Barr Virus. Curr Top Microbiol Immunol (2015) 390(Pt 1):339-63. doi: 10.1007/978-3-319-22822-8_14

131. Qiu J, Smith P, Leahy L, Thorley-Lawson DA. The Epstein-Barr Virus Encoded BART miRNAs Potentiate Tumor Growth In Vivo. PloS Pathog (2015) 11(1):e1004561. doi: 10.1371/journal.ppat.1004561

132. Cosmopoulos K, Pegtel M, Hawkins J, Moffett H, Novina C, Middeldorp J, et al. Comprehensive Profiling of Epstein-Barr Virus microRNAs in Nasopharyngeal Carcinoma. J Virol (2009) 83(5):2357-67. doi: 10.1128/ JVI.02104-08 
133. Fotheringham JA, Coalson NE, Raab-Traub N. Epstein-Barr Virus Latent Membrane Protein-2A Induces ITAM/Syk- and Akt-Dependent Epithelial Migration Through Alphav-Integrin Membrane Translocation. J Virol (2012) 86(19):10308-20. doi: 10.1128/JVI.00853-12

134. Pegtel DM, Subramanian A, Sheen TS, Tsai CH, Golub TR, Thorley-Lawson DA. Epstein-Barr-Virus-Encoded LMP2A Induces Primary Epithelial Cell Migration and Invasion: Possible Role in Nasopharyngeal Carcinoma Metastasis. J Virol (2005) 79(24):15430-42. doi: 10.1128/JVI.79.24.1543015442.2005

135. Thornburg NJ, Pathmanathan R, Raab-Traub N. Activation of Nuclear factor-kappaB P50 Homodimer/Bcl-3 Complexes in Nasopharyngeal Carcinoma. Cancer Res (2003) 63(23):8293-301.

136. Fukayama M, Ushiku T. Epstein-Barr Virus-Associated Gastric Carcinoma. Pathol Res Pract (2011) 207(9):529-37. doi: 10.1016/j.prp.2011.07.004

137. Song HJ, Kim KM. Pathology of Epstein-Barr Virus-Associated Gastric Carcinoma and Its Relationship to Prognosis. Gut Liver (2011) 5(2):143-8. doi: $10.5009 /$ gnl.2011.5.2.143

138. van Beek J, zur Hausen A, Klein Kranenbarg E, van de Velde CJ, Middeldorp JM, van den Brule AJ, et al. EBV-Positive Gastric Adenocarcinomas: A Distinct Clinicopathologic Entity With a Low Frequency of Lymph Node Involvement. J Clin Oncol (2004) 22(4):664-70. doi: 10.1200/ JCO.2004.08.061

139. Ribeiro J, Oliveira C, Malta M, Sousa H. Epstein-Barr Virus Gene Expression and Latency Pattern in Gastric Carcinomas: A Systematic Review. Future Oncol (2017) 13(6):567-79. doi: 10.2217/fon-2016-0475

140. Cancer Genome Atlas Research N. Comprehensive Molecular Characterization of Gastric Adenocarcinoma. Nature (2014) 513 (7517):202-9. doi: 10.1038/nature13480

141. Abe H, Kaneda A, Fukayama M. Epstein-Barr Virus-Associated Gastric Carcinoma: Use of Host Cell Machineries and Somatic Gene Mutations. Pathobiology (2015) 82(5):212-23. doi: 10.1159/000434683

142. Kaneda A, Matsusaka K, Aburatani H, Fukayama M. Epstein-Barr Virus Infection as an Epigenetic Driver of Tumorigenesis. Cancer Res (2012) 72 (14):3445-50. doi: 10.1158/0008-5472.CAN-11-3919

143. McKay KA, Kwan V, Duggan T, Tremlett H. Risk Factors Associated With the Onset of Relapsing-Remitting and Primary Progressive Multiple Sclerosis: A Systematic Review. BioMed Res Int (2015) 2015:817238. doi: $10.1155 / 2015 / 817238$

144. Ascherio A, Munger KL. Epstein-Barr Virus Infection and Multiple Sclerosis: A Review. J Neuroimmune Pharmacol (2010) 5(3):271-7. doi: 10.1007/ s11481-010-9201-3

145. Jons D, Sundstrom P, Andersen O. Targeting Epstein-Barr Virus Infection as an Intervention Against Multiple Sclerosis. Acta Neurol Scand (2015) 131 (2):69-79. doi: 10.1111/ane.12294

146. Pender MP, Csurhes PA, Smith C, Douglas NL, Neller MA, Matthews KK, et al. Epstein-Barr Virus-Specific T Cell Therapy for Progressive Multiple Sclerosis. JCI Insight (2018) 3(22). doi: 10.1172/jci.insight.124714

147. Polepole P, Bartenslager A, Liu Y, Petro TM, Fernando S, Zhang L. EpsteinBarr Virus-Immortalized B Lymphocytes Exacerbate Experimental Autoimmune Encephalomyelitis in Xenograft Mice. J Med Virol (2021) 93 (6):3813-23. doi: 10.1002/jmv.26188

148. Zdimerova H, Murer A, Engelmann C, Raykova A, Deng Y, Gujer C, et al. Attenuated Immune Control of Epstein-Barr Virus in Humanized Mice is Associated With the Multiple Sclerosis Risk Factor HLA-Dr15. Eur J Immunol (2021) 51(1):64-75. doi: 10.1002/eji.202048655

149. Nielsen TR, Rostgaard K, Askling J, Steffensen R, Oturai A, Jersild C, et al. Effects of Infectious Mononucleosis and HLA-DRB1 ${ }^{\star} 15$ in Multiple Sclerosis. Mult Scler (2009) 15(4):431-6. doi: 10.1177/1352458508100037

150. de Martel C, Ferlay J, Franceschi S, Vignat J, Bray F, Forman D, et al. Global Burden of Cancers Attributable to Infections in 2008: A Review and Synthetic Analysis. Lancet Oncol (2012) 13(6):607-15. doi: 10.1016/S14702045(12)70137-7

151. Epstein MA, Morgan AJ, Finerty S, Randle BJ, Kirkwood JK. Protection of Cottontop Tamarins Against Epstein-Barr Virus-Induced Malignant Lymphoma by a Prototype Subunit Vaccine. Nature (1985) 318 (6043):287-9. doi: 10.1038/318287a0

152. Emini EA, Schleif WA, Armstrong ME, Silberklang M, Schultz LD, Lehman D, et al. Antigenic Analysis of the Epstein-Barr Virus Major Membrane
Antigen (Gp350/220) Expressed in Yeast and Mammalian Cells: Implications for the Development of a Subunit Vaccine. Virology (1988) 166(2):387-93. doi: 10.1016/0042-6822(88)90509-0

153. Morgan AJ, Finerty S, Lovgren K, Scullion FT, Morein B. Prevention of Epstein-Barr (EB) Virus-Induced Lymphoma in Cottontop Tamarins by Vaccination With the EB Virus Envelope Glycoprotein Gp340 Incorporated Into Immune-Stimulating Complexes. J Gen Virol (1988) 69( Pt 8):2093-6. doi: 10.1099/0022-1317-69-8-2093

154. Finerty S, Mackett M, Arrand JR, Watkins PE, Tarlton J, Morgan AJ. Immunization of Cottontop Tamarins and Rabbits With a Candidate Vaccine Against the Epstein-Barr Virus Based on the Major Viral Envelope Glycoprotein Gp340 and Alum. Vaccine (1994) 12(13):1180-4. doi: 10.1016/0264-410X(94)90240-2

155. Jackman WT, Mann KA, Hoffmann HJ, Spaete RR. Expression of EpsteinBarr Virus Gp350 as a Single Chain Glycoprotein for an EBV Subunit Vaccine. Vaccine (1999) 17(7-8):660-8. doi: 10.1016/S0264-410X(98) 00248-5

156. Sokal EM, Hoppenbrouwers K, Vandermeulen C, Moutschen M, Leonard P, Moreels A, et al. Recombinant Gp350 Vaccine for Infectious Mononucleosis: A Phase 2, Randomized, Double-Blind, Placebo-Controlled Trial to Evaluate the Safety, Immunogenicity, and Efficacy of an Epstein-Barr Virus Vaccine in Healthy Young Adults. J Infect Dis (2007) 196(12):1749-53. doi: 10.1086/ 523813

157. Cui X, Cao Z, Sen G, Chattopadhyay G, Fuller DH, Fuller JT, et al. A Novel Tetrameric Gp350 1-470 as a Potential Epstein-Barr Virus Vaccine. Vaccine (2013) 31(30):3039-45. doi: 10.1016/j.vaccine.2013.04.071

158. Kanekiyo M, Bu W, Joyce MG, Meng G, Whittle JR, Baxa U, et al. Rational Design of an Epstein-Barr Virus Vaccine Targeting the Receptor-Binding Site. Cell (2015) 162(5):1090-100. doi: 10.1016/j.cell.2015.07.043

159. Cui X, Cao Z, Chen Q, Arjunaraja S, Snow AL, Snapper CM. Rabbits Immunized With Epstein-Barr Virus Gh/gL or gB Recombinant Proteins Elicit Higher Serum Virus Neutralizing Activity Than Gp350. Vaccine (2016) 34(34):4050-5. doi: 10.1016/j.vaccine.2016.06.021

160. Zhao B, Zhang X, Krummenacher C, Song S, Gao L, Zhang H, et al. Immunization With Fc-Based Recombinant Epstein-Barr Virus Gp350 Elicits Potent Neutralizing Humoral Immune Response in a BALB/c Mice Model. Front Immunol (2018) 9:932. doi: 10.3389/fimmu.2018.00932

161. Bu W, Joyce MG, Nguyen H, Banh DV, Aguilar F, Tariq Z, et al. Immunization With Components of the Viral Fusion Apparatus Elicits Antibodies That Neutralize Epstein-Barr Virus in B Cells and Epithelial Cells. Immunity (2019) 50(5):1305-16 e6. doi: 10.1016/ j.immuni.2019.03.010

162. Cui X, Cao Z, Ishikawa Y, Cui S, Imadome KI, Snapper CM. Immunization With Epstein-Barr Virus Core Fusion Machinery Envelope Proteins Elicit High Titers of Neutralizing Activities and Protect Humanized Mice From Lethal Dose EBV Challenge. Vaccines (Basel) (2021) 9(3). doi: 10.3390/ vaccines 9030285

163. Ruiss R, Jochum S, Wanner G, Reisbach G, Hammerschmidt W, Zeidler R. A Virus-Like Particle-Based Epstein-Barr Virus Vaccine. J Virol (2011) 85 (24):13105-13. doi: 10.1128/JVI.05598-11

164. van Zyl DG, Tsai MH, Shumilov A, Schneidt V, Poirey R, Schlehe B, et al. Immunogenic Particles With a Broad Antigenic Spectrum Stimulate Cytolytic T Cells and Offer Increased Protection Against EBV Infection Ex Vivo and in Mice. PloS Pathog (2018) 14(12):e1007464. doi: 10.1371/ journal.ppat.1007464

165. Ogembo JG, Muraswki MR, McGinnes LW, Parcharidou A, Sutiwisesak R, Tison T, et al. A Chimeric EBV Gp350/220-Based VLP Replicates the Virion BCell Attachment Mechanism and Elicits Long-Lasting Neutralizing Antibodies in Mice. J Transl Med (2015) 13:50. doi: 10.1186/s12967-015-0415-2

166. Perez EM, Foley J, Tison T, Silva R, Ogembo JG. Novel Epstein-Barr VirusLike Particles Incorporating Gh/gL-EBNA1 or gB-LMP2 Induce High Neutralizing Antibody Titers and EBV-Specific T-Cell Responses in Immunized Mice. Oncotarget (2017) 8(12):19255-73. doi: 10.18632/ oncotarget. 13770

167. Moutschen M, Leonard P, Sokal EM, Smets F, Haumont M, Mazzu P, et al Phase I/II Studies to Evaluate Safety and Immunogenicity of a Recombinant Gp350 Epstein-Barr Virus Vaccine in Healthy Adults. Vaccine (2007) 25 (24):4697-705. doi: 10.1016/j.vaccine.2007.04.008 
168. Janz A, Oezel M, Kurzeder C, Mautner J, Pich D, Kost M, et al. Infectious Epstein-Barr Virus Lacking Major Glycoprotein BLLF1 (Gp350/220) Demonstrates the Existence of Additional Viral Ligands. J Virol (2000) 74 (21):10142-52. doi: 10.1128/JVI.74.21.10142-10152.2000

169. Draper SJ, Angov E, Horii T, Miller LH, Srinivasan P, Theisen M, et al. Recent Advances in Recombinant Protein-Based Malaria Vaccines. Vaccine (2015) 33(52):7433-43. doi: 10.1016/j.vaccine.2015.09.093

170. Hjerrild KA, Jin J, Wright KE, Brown RE, Marshall JM, Labbe GM, et al. Production of Full-Length Soluble Plasmodium Falciparum RH5 Protein Vaccine Using a Drosophila Melanogaster Schneider 2 Stable Cell Line System. Sci Rep (2016) 6:30357. doi: 10.1038/srep30357

171. Diamond DJ, La Rosa C, Chiuppesi F, Contreras H, Dadwal S, Wussow F, et al. A Fifty-Year Odyssey: Prospects for a Cytomegalovirus Vaccine in Transplant and Congenital Infection. Expert Rev Vaccines (2018) 17 (10):889-911. doi: 10.1080/14760584.2018.1526085

172. Cui X, Snapper CM. Development of Novel Vaccines Against Human Cytomegalovirus. Hum Vaccin Immunother (2019) 15(11):2673-83. doi: 10.1080/21645515.2019.1593729

173. Cui X, Cao Z, Wang S, Lee RB, Wang X, Murata H, et al. Novel Trimeric Human Cytomegalovirus Glycoprotein B Elicits a High-Titer Neutralizing Antibody Response. Vaccine (2018) 36(37):5580-90. doi: 10.1016/ j.vaccine.2018.07.056

174. Cui X, Cao Z, Wang S, Adler SP, McVoy MA, Snapper CM. Immunization With Human Cytomegalovirus Core Fusion Machinery and Accessory Envelope Proteins Elicit Strong Synergistic Neutralizing Activities. Vaccines (Basel) (2020) 8(2). doi: 10.3390/vaccines8020179

175. Cui, Xinle, Snapper, Clifford M. Vaccine Compositions of Herpesvirus Envelope Protein Combinations to Induce Immune Response. USPTO (2021) 20210163542.

176. Brooks JM, Long HM, Tierney RJ, Shannon-Lowe C, Leese AM, Fitzpatrick M, et al. Early T Cell Recognition of B Cells Following Epstein-Barr Virus Infection: Identifying Potential Targets for Prophylactic Vaccination. PloS Pathog (2016) 12(4):e1005549. doi: 10.1371/journal.ppat.1005549

177. Adhikary D, Behrends U, Moosmann A, Witter K, Bornkamm GW, Mautner J. Control of Epstein-Barr Virus Infection In Vitro by T Helper Cells Specific for Virion Glycoproteins. J Exp Med (2006) 203(4):995-1006. doi: 10.1084/ jem. 20051287

178. Forni G, Mantovani A. Covid-19 Commission of Accademia Nazionale Dei Lincei R. COVID-19 Vaccines: Where We Stand and Challenges Ahead. Cell Death Differ (2021) 28(2):626-39. doi: 10.1038/s41418-020-00720-9

179. Kyriakidis NC, Lopez-Cortes A, Gonzalez EV, Grimaldos AB, Prado EO. SARS-CoV-2 Vaccines Strategies: A Comprehensive Review of Phase 3 Candidates. NPJ Vaccines (2021) 6(1):28. doi: 10.1038/s41541-021-00292-w

180. Munz C, Bickham KL, Subklewe M, Tsang ML, Chahroudi A, Kurilla MG, et al. Human CD4(+) T Lymphocytes Consistently Respond to the Latent Epstein-Barr Virus Nuclear Antigen EBNA1. J Exp Med (2000) 191 (10):1649-60. doi: 10.1084/jem.191.10.1649

181. Fu T, Voo KS, Wang RF. Critical Role of EBNA1-Specific CD4+ T Cells in the Control of Mouse Burkitt Lymphoma In Vivo. J Clin Invest (2004) 114 (4):542-50. doi: 10.1172/JCI22053

182. Tellam J, Connolly G, Green KJ, Miles JJ, Moss DJ, Burrows SR, et al. Endogenous Presentation of CD8+ T Cell Epitopes From Epstein-Barr Virus-Encoded Nuclear Antigen 1. J Exp Med (2004) 199(10):1421-31. doi: $10.1084 /$ jem.20040191

183. Brooks L, Yao QY, Rickinson AB, Young LS. Epstein-Barr Virus Latent Gene Transcription in Nasopharyngeal Carcinoma Cells: Coexpression of EBNA1, LMP1, and LMP2 Transcripts. J Virol (1992) 66(5):2689-97. doi: 10.1128/ jvi.66.5.2689-2697.1992

184. Lee SP, Tierney RJ, Thomas WA, Brooks JM, Rickinson AB. Conserved CTL Epitopes Within EBV Latent Membrane Protein 2: A Potential Target for CTL-Based Tumor Therapy. J Immunol (1997) 158(7):3325-34.

185. Straathof KC, Leen AM, Buza EL, Taylor G, Huls MH, Heslop HE, et al. Characterization of Latent Membrane Protein 2 Specificity in CTL Lines From Patients With EBV-Positive Nasopharyngeal Carcinoma and Lymphoma. J Immunol (2005) 175(6):4137-47. doi: 10.4049/ jimmunol.175.6.4137

186. Huang J, Fogg M, Wirth LJ, Daley H, Ritz J, Posner MR, et al. Epstein-Barr Virus-Specific Adoptive Immunotherapy for Recurrent, Metastatic
Nasopharyngeal Carcinoma. Cancer (2017) 123(14):2642-50. doi: 10.1002/ cncr.30541

187. Li F, Song D, Lu Y, Zhu H, Chen Z, He X. Delayed-Type Hypersensitivity (DTH) Immune Response Related With EBV-DNA in Nasopharyngeal Carcinoma Treated With Autologous Dendritic Cell Vaccination After Radiotherapy. J Immunother (2013) 36(3):208-14. doi: 10.1097/ CJI.0b013e31828bd87b

188. Si Y, Deng Z, Lan G, Du H, Wang Y, Si J, et al. The Safety and Immunological Effects of Rad5-EBV-LMP2 Vaccine in Nasopharyngeal Carcinoma Patients: A Phase I Clinical Trial and Two-Year Follow-Up. Chem Pharm Bull (Tokyo) (2016) 64(8):1118-23. doi: 10.1248/cpb.c16-00114

189. Hui EP, Taylor GS, Jia H, Ma BB, Chan SL, Ho R, et al. Phase I Trial of Recombinant Modified Vaccinia Ankara Encoding Epstein-Barr Viral Tumor Antigens in Nasopharyngeal Carcinoma Patients. Cancer Res (2013) 73(6):1676-88. doi: 10.1158/0008-5472.CAN-12-2448

190. Taylor GS, Jia H, Harrington K, Lee LW, Turner J, Ladell K, et al. A Recombinant Modified Vaccinia Ankara Vaccine Encoding Epstein-Barr Virus (EBV) Target Antigens: A Phase I Trial in UK Patients With EBVPositive Cancer. Clin Cancer Res (2014) 20(19):5009-22. doi: 10.1158/10780432.CCR-14-1122-T

191. Lin CL, Lo WF, Lee TH, Ren Y, Hwang SL, Cheng YF, et al. Immunization With Epstein-Barr Virus (EBV) Peptide-Pulsed Dendritic Cells Induces Functional CD8+ T-Cell Immunity and may Lead to Tumor Regression in Patients With EBV-Positive Nasopharyngeal Carcinoma. Cancer Res (2002) 62(23):6952-8.

192. Taylor GS, Haigh TA, Gudgeon NH, Phelps RJ, Lee SP, Steven NM, et al. Dual Stimulation of Epstein-Barr Virus (EBV)-Specific CD4+- and CD8+-TCell Responses by a Chimeric Antigen Construct: Potential Therapeutic Vaccine for EBV-Positive Nasopharyngeal Carcinoma. J Virol (2004) 78 (2):768-78. doi: 10.1128/JVI.78.2.768-778.2004

193. Coghill AE, Bu W, Nguyen H, Hsu WL, Yu KJ, Lou PJ, et al. High Levels of Antibody That Neutralize B-Cell Infection of Epstein-Barr Virus and That Bind EBV Gp350 Are Associated With a Lower Risk of Nasopharyngeal Carcinoma. Clin Cancer Res (2016) 22(14):3451-7. doi: 10.1158/1078-0432.CCR-15-2299

194. Papadopoulos EB, Ladanyi M, Emanuel D, Mackinnon S, Boulad F, Carabasi MH, et al. Infusions of Donor Leukocytes to Treat Epstein-Barr VirusAssociated Lymphoproliferative Disorders After Allogeneic Bone Marrow Transplantation. N Engl J Med (1994) 330(17):1185-91. doi: 10.1056/ NEJM199404283301703

195. Khanna R, Bell S, Sherritt M, Galbraith A, Burrows SR, Rafter L, et al. Activation and Adoptive Transfer of Epstein-Barr Virus-Specific Cytotoxic T Cells in Solid Organ Transplant Patients With Posttransplant Lymphoproliferative Disease. Proc Natl Acad Sci U.S.A. (1999) 96 (18):10391-6. doi: 10.1073/pnas.96.18.10391

196. Savoldo B, Goss JA, Hammer MM, Zhang L, Lopez T, Gee AP, et al. Treatment of Solid Organ Transplant Recipients With Autologous Epstein Barr Virus-Specific Cytotoxic T Lymphocytes (CTLs). Blood (2006) 108 (9):2942-9. doi: 10.1182/blood-2006-05-021782

197. Comoli P, Labirio M, Basso S, Baldanti F, Grossi P, Furione M, et al. Infusion of Autologous Epstein-Barr Virus (EBV)-Specific Cytotoxic T Cells for Prevention of EBV-Related Lymphoproliferative Disorder in Solid Organ Transplant Recipients With Evidence of Active Virus Replication. Blood (2002) 99(7):2592-8. doi: 10.1182/blood.V99.7.2592

198. Comoli P, Pedrazzoli P, Maccario R, Basso S, Carminati O, Labirio M, et al. Cell Therapy of Stage IV Nasopharyngeal Carcinoma With Autologous Epstein-Barr Virus-Targeted Cytotoxic T Lymphocytes. J Clin Oncol (2005) 23(35):8942-9. doi: 10.1200/JCO.2005.02.6195

199. Louis CU, Straathof K, Bollard CM, Ennamuri S, Gerken C, Lopez TT, et al. Adoptive Transfer of EBV-Specific T Cells Results in Sustained Clinical Responses in Patients With Locoregional Nasopharyngeal Carcinoma. J Immunother (2010) 33(9):983-90. doi: 10.1097/CJI.0b013e3181f3cbf4

200. Chia WK, Teo M, Wang WW, Lee B, Ang SF, Tai WM, et al. Adoptive T-Cell Transfer and Chemotherapy in the First-Line Treatment of Metastatic and/ or Locally Recurrent Nasopharyngeal Carcinoma. Mol Ther (2014) 22 (1):132-9. doi: 10.1038/mt.2013.242

201. Bollard CM, Gottschalk S, Torrano V, Diouf O, Ku S, Hazrat Y, et al. Sustained Complete Responses in Patients With Lymphoma Receiving Autologous Cytotoxic T Lymphocytes Targeting Epstein-Barr Virus Latent 
Membrane Proteins. J Clin Oncol (2014) 32(8):798-808. doi: 10.1200/ JCO.2013.51.5304

202. Zheng Y, Parsonage G, Zhuang X, Machado LR, James CH, Salman A, et al. Human Leukocyte Antigen (HLA) A*1101-Restricted Epstein-Barr Virus-Specific T-Cell Receptor Gene Transfer to Target Nasopharyngeal Carcinoma. Cancer Immunol Res (2015) 3(10):1138-47. doi: 10.1158/2326-6066.CIR-14-0203-T

203. Cho HI, Kim UH, Shin AR, Won JN, Lee HJ, Sohn HJ, et al. A Novel EpsteinBarr Virus-Latent Membrane Protein-1-Specific T-Cell Receptor for TCR Gene Therapy. Br J Cancer (2018) 118(4):534-45. doi: 10.1038/bjc.2017.475

204. Tang X, Tang Q, Mao Y, Huang X, Jia L, Zhu J, et al. CD137 Co-Stimulation Improves The Antitumor Effect Of LMP1-Specific Chimeric Antigen Receptor T Cells In Vitro And In Vivo. Onco Targets Ther (2019) 12:9341-50. doi: 10.2147/OTT.S221040

205. Tang X, Zhou Y, Li W, Tang Q, Chen R, Zhu J, et al. T Cells Expressing a LMP1-Specific Chimeric Antigen Receptor Mediate Antitumor Effects Against LMP1-Positive Nasopharyngeal Carcinoma Cells In Vitro and In Vivo. J BioMed Res (2014) 28(6):468-75. doi: 10.7555/JBR.28.20140066

206. Roskrow MA, Suzuki N, Gan Y, Sixbey JW, Ng CY, Kimbrough S, et al. EpsteinBarr Virus (EBV)-Specific Cytotoxic T Lymphocytes for the Treatment of Patients With EBV-Positive Relapsed Hodgkin's Disease. Blood (1998) 91 (8):2925-34. doi: 10.1182/blood.V91.8.2925.2925_2925_2934

207. Smith C, Lee V, Schuessler A, Beagley L, Rehan S, Tsang J, et al. Pre-Emptive and Therapeutic Adoptive Immunotherapy for Nasopharyngeal Carcinoma: Phenotype and Effector Function of T Cells Impact on Clinical Response. Oncoimmunology (2017) 6(2):e1273311. doi: 10.1080/2162402X.2016.1273311

208. Gottschalk S, Edwards OL, Sili U, Huls MH, Goltsova T, Davis AR, et al. Generating CTLs Against the Subdominant Epstein-Barr Virus LMP1 Antigen for the Adoptive Immunotherapy of EBV-Associated Malignancies. Blood (2003) 101(5):1905-12. doi: 10.1182/blood-2002-05-1514

209. Nagarsheth NB, Norberg SM, Sinkoe AL, Adhikary S, Meyer TJ, Lack JB, et al. TCR-Engineered T Cells Targeting E7 for Patients With Metastatic HPV-Associated Epithelial Cancers. Nat Med (2021) 27(3):419-25. doi: 10.1038/s41591-020-01225-1

210. Manfredi F, Cianciotti BC, Potenza A, Tassi E, Noviello M, Biondi A, et al. TCR Redirected T Cells for Cancer Treatment: Achievements, Hurdles, and Goals. Front Immunol (2020) 11:1689. doi: 10.3389/fimmu.2020.01689

211. Zhao L, Cao YJ. Engineered T Cell Therapy for Cancer in the Clinic. Front Immunol (2019) 10:2250. doi: 10.3389/fimmu.2019.02250

212. Orentas RJ, Roskopf SJ, Nolan GP, Nishimura MI. Retroviral Transduction of a T Cell Receptor Specific for an Epstein-Barr Virus-Encoded Peptide. Clin Immunol (2001) 98(2):220-8. doi: 10.1006/clim.2000.4977

213. Schaft N, Lankiewicz B, Drexhage J, Berrevoets C, Moss DJ, Levitsky V, et al. T Cell Re-Targeting to EBV Antigens Following TCR Gene Transfer: CD28Containing Receptors Mediate Enhanced Antigen-Specific IFNgamma Production. Int Immunol (2006) 18(4):591-601. doi: 10.1093/intimm/dxh401

214. Kobayashi E, Mizukoshi E, Kishi H, Ozawa T, Hamana H, Nagai T, et al. A New Cloning and Expression System Yields and Validates TCRs From Blood Lymphocytes of Patients With Cancer Within 10 Days. Nat Med (2013) 19 (11):1542-6. doi: 10.1038/nm.3358

215. Yang D, Shao Q, Sun H, Mu X, Gao Y, Jiang R, et al. Evaluation of EpsteinBarr Virus Latent Membrane Protein 2 Specific T-Cell Receptors Driven by T-Cell Specific Promoters Using Lentiviral Vector. Clin Dev Immunol (2011) 2011:716926. doi: 10.1155/2011/716926

216. Munz C. Redirecting T Cells Against Epstein-Barr Virus Infection and Associated Oncogenesis. Cells (2020) 9(6). doi: 10.3390/cells9061400
217. Xue SA, Gao L, Ahmadi M, Ghorashian S, Barros RD, Pospori C, et al. Human MHC Class I-Restricted High Avidity CD4(+) T Cells Generated by Co-Transfer of TCR and CD8 Mediate Efficient Tumor Rejection In Vivo. Oncoimmunology (2013) 2(1):e22590. doi: 10.4161/onci.22590

218. Chatterjee B, Deng Y, Holler A, Nunez N, Azzi T, Vanoaica LD, et al. CD8+ T Cells Retain Protective Functions Despite Sustained Inhibitory Receptor Expression During Epstein-Barr Virus Infection In Vivo. PloS Pathog (2019) 15(5):e1007748. doi: 10.1371/journal.ppat.1007748

219. Savoldo B, Rooney CM, Di Stasi A, Abken H, Hombach A, Foster AE, et al. Epstein Barr Virus Specific Cytotoxic T Lymphocytes Expressing the AntiCD30zeta Artificial Chimeric T-Cell Receptor for Immunotherapy of Hodgkin Disease. Blood (2007) 110(7):2620-30. doi: 10.1182/blood-200611-059139

220. Cruz CR, Micklethwaite KP, Savoldo B, Ramos CA, Lam S, Ku S, et al. Infusion of Donor-Derived CD19-Redirected Virus-Specific T Cells for BCell Malignancies Relapsed After Allogeneic Stem Cell Transplant: A Phase 1 Study. Blood (2013) 122(17):2965-73. doi: 10.1182/blood-201306-506741

221. Fousek K, Watanabe J, Joseph SK, George A, An X, Byrd TT, et al. CAR TCells That Target Acute B-Lineage Leukemia Irrespective of CD19 Expression. Leukemia (2021) 35(1):75-89. doi: 10.1038/s41375-0200792-2

222. Liu E, Marin D, Banerjee P, Macapinlac HA, Thompson P, Basar R, et al. Use of CAR-Transduced Natural Killer Cells in CD19-Positive Lymphoid Tumors. N Engl J Med (2020) 382(6):545-53. doi: 10.1056/ NEJMoa1910607

223. Wang M, Munoz J, Goy A, Locke FL, Jacobson CA, Hill BT, et al. KTE-X19 CAR T-Cell Therapy in Relapsed or Refractory Mantle-Cell Lymphoma. $N$ Engl J Med (2020) 382(14):1331-42. doi: 10.1056/NEJMoa1914347

224. Cunningham-Rundles C. Common Variable Immune Deficiency: Case Studies. Blood (2019) 134(21):1787-95. doi: 10.1182/blood.2019002062

Author Disclaimer: The opinions expressed herein are those of the authors and are not necessarily representative of those of USUHS, the United States Army, Navy or Air Force, or the Department of Defense (DOD). The funders had no role in the design of the study; in the collection, analyses, or interpretation of data; in the writing of the manuscript, or in the decision to publish the results.

Conflict of Interest: CMS was employed by Citranvi Biosciences LLC. XC and CMS are inventors of a patent for vaccine development using herpesvirus trimeric $\mathrm{gB}$ proteins, and a pending patent using key envelope proteins combination in vaccine development.

Publisher's Note: All claims expressed in this article are solely those of the authors and do not necessarily represent those of their affiliated organizations, or those of the publisher, the editors and the reviewers. Any product that may be evaluated in this article, or claim that may be made by its manufacturer, is not guaranteed or endorsed by the publisher.

Copyright $(2021$ Cui and Snapper. This is an open-access article distributed under the terms of the Creative Commons Attribution License (CC BY). The use, distribution or reproduction in other forums is permitted, provided the original author(s) and the copyright owner(s) are credited and that the original publication in this journal is cited, in accordance with accepted academic practice. No use, distribution or reproduction is permitted which does not comply with these terms. 